Article

\title{
Preparation of High-Purity Ammonium Tetrakis(pentafluorophenyl)borate for the Activation of Olefin Polymerization Catalysts
}

\author{
Hyun-Ju Lee ${ }^{1,+} \mathbb{D}^{\mathbb{D}}$, Jun-Won Baek ${ }^{1,+}{ }^{\oplus}$, Yeong-Hyun Seo ${ }^{1}$, Hong-Cheol Lee ${ }^{1}$, Sun-Mi Jeong ${ }^{1}$, Junseong Lee ${ }^{2}{ }^{-}$, \\ Chong-Gu Lee ${ }^{3}$ i) and Bun-Yeoul Lee ${ }^{1, *(1)}$ \\ 1 Department of Molecular Science and Technology, Ajou University, Suwon 16499, Korea; \\ hjulee4639@ajou.ac.kr (H.-J.L.); btw91@ajou.ac.kr (J.-W.B.); tdg0730@ajou.ac.kr (Y.-H.S.); \\ asdfg7235950@gmail.com (H.-C.L.); sunmi7523@ajou.ac.kr (S.-M.J.) \\ 2 Department of Chemistry, Chonnam National University, 77 Yongbong-ro, Buk-gu, Gwangju 61186, Korea; \\ leespy@chonnam.ac.kr \\ 3 Precious Catalysts Inc., 201 Duryu-gil, Angangeup, Gyeongju 38029, Korea; cglee@s-pci.com \\ * Correspondence: bunyeoul@ajou.ac.kr; Tel.: +82-31-219-1844 \\ + These authors contributed equally to this work.
}

check for

updates

Citation: Lee, H.-J.; Baek, J.-W.; Seo, Y.-H.; Lee, H.-C.; Jeong, S.-M.; Lee, J.; Lee, C.-G.; Lee, B.-Y. Preparation of High-Purity Ammonium

Tetrakis(pentafluorophenyl)borate for the Activation of Olefin

Polymerization Catalysts. Molecules 2021, 26, 2827. https://doi.org/

$10.3390 /$ molecules 26092827

Academic Editor: Elena V. Grachova

Received: 10 April 2021

Accepted: 7 May 2021

Published: 10 May 2021

Publisher's Note: MDPI stays neutral with regard to jurisdictional claims in published maps and institutional affiliations.

Copyright: (C) 2021 by the authors Licensee MDPI, Basel, Switzerland. This article is an open access article distributed under the terms and conditions of the Creative Commons Attribution (CC BY) license (https:// creativecommons.org/licenses/by/ $4.0 /)$.

\begin{abstract}
Homogeneous olefin polymerization catalysts are activated in situ with a co-catalyst $\left(\left[\mathrm{PhN}(\mathrm{Me})_{2}-\mathrm{H}\right]^{+}\left[\mathrm{B}\left(\mathrm{C}_{6} \mathrm{~F}_{5}\right)_{4}\right]^{-}\right.$or $\left.\left[\mathrm{Ph}_{3} \mathrm{C}\right]^{+}\left[\mathrm{B}\left(\mathrm{C}_{6} \mathrm{~F}_{5}\right)_{4}\right]^{-}\right)$in bulk polymerization media. These co-catalysts are insoluble in hydrocarbon solvents, requiring excess co-catalyst ( $>3$ eq.). Feeding the activated species as a solution in an aliphatic hydrocarbon solvent may be advantageous over the in situ activation method. In this study, highly pure and soluble ammonium tetrakis(pentafluorophenyl)borates $\left(\left[\mathrm{Me}\left(\mathrm{C}_{18} \mathrm{H}_{37}\right)_{2} \mathrm{~N}-\mathrm{H}\right]^{+}\left[\mathrm{B}\left(\mathrm{C}_{6} \mathrm{~F}_{5}\right)_{4}\right]^{-}\right.$and $\left.\left[\left(\mathrm{C}_{18} \mathrm{H}_{37}\right)_{2} \mathrm{NH}_{2}\right]^{+}\left[\mathrm{B}\left(\mathrm{C}_{6} \mathrm{~F}_{5}\right)_{4}\right]^{-}\right)$containing neither water nor $\mathrm{Cl}^{-}$ salt impurities were prepared easily via the acid-base reaction of $\left[\mathrm{PhN}(\mathrm{Me})_{2}-\mathrm{H}\right]^{+}\left[\mathrm{B}\left(\mathrm{C}_{6} \mathrm{~F}_{5}\right)_{4}\right]^{-}$and the corresponding amine. Using the prepared ammonium salts, the activation reactions of commercialprocess-relevant metallocene (rac-[ethylenebis(tetrahydroindenyl)] $\left.\mathrm{Zr}(\mathrm{Me})_{2}(\mathbf{1}-\mathrm{ZrMe})_{2}\right),\left[\mathrm{Ph}_{2} \mathrm{C}(\mathrm{Cp})(3,6-\right.$ $\left.\left.\left.{ }^{t} \mathrm{Bu}_{2} \mathrm{Flu}\right)\right] \mathrm{Hf}(\mathrm{Me})_{2}\left(3-\mathrm{HfMe}_{2}\right),\left[\mathrm{Ph}_{2} \mathrm{C}(\mathrm{Cp})\left(2,7-{ }^{t} \mathrm{Bu}_{2} \mathrm{Flu}\right)\right] \mathrm{Hf}(\mathrm{Me})_{2}\left(4-\mathrm{HfMe}_{2}\right)\right)$ and half-metallocene complexes $\left(\left[\left(\eta^{5}-\mathrm{Me}_{4} \mathrm{C}_{5}\right) \mathrm{Si}(\mathrm{Me})_{2}\left(\kappa-\mathrm{N}^{t} \mathrm{Bu}\right)\right] \mathrm{Ti}(\mathrm{Me})_{2}\left(5-\mathrm{TiMe}_{2}\right),\left[\left(\eta^{5}-\mathrm{Me}_{4} \mathrm{C}_{5}\right)\left(\mathrm{C}_{9} \mathrm{H}_{9}(\kappa-\mathrm{N})\right)\right] \mathrm{Ti}(\mathrm{Me})_{2}\right.$ (6$\left.\mathrm{TiMe}_{2}\right)$, and $\left.\left[\left(\eta^{5}-\mathrm{Me}_{3} \mathrm{C}_{7} \mathrm{H}_{1} \mathrm{~S}\right)\left(\mathrm{C}_{10} \mathrm{H}_{11}(\mathrm{k}-\mathrm{N})\right)\right] \mathrm{Ti}(\mathrm{Me})_{2}\left(7-\mathrm{TiMe}_{2}\right)\right)$ were monitored in $\mathrm{C}_{6} \mathrm{D}_{12}$ with ${ }^{1} \mathrm{H}$ NMR spectroscopy. Stable $\left[\mathbf{L}-\mathrm{M}(\mathrm{Me})\left(\mathrm{NMe}\left(\mathrm{C}_{18} \mathrm{H}_{37}\right)_{2}\right)\right]^{+}\left[\mathrm{B}\left(\mathrm{C}_{6} \mathrm{~F}_{5}\right)_{4}\right]^{-}$species were cleanly generated from 1-ZrMe $2,3-\mathrm{HfMe}_{2}$, and 4- $\mathrm{HfMe}_{2}$, while the species types generated from 5-TiMe, 6 $\mathrm{TiMe}_{2}$, and 7-TiMe 2 were unstable for subsequent transformation to other species (presumably, [L$\left.\mathrm{Ti}\left(\mathrm{CH}_{2} \mathrm{~N}\left(\mathrm{C}_{18} \mathrm{H}_{37}\right)_{2}\right)\right]^{+}\left[\mathrm{B}\left(\mathrm{C}_{6} \mathrm{~F}_{5}\right)_{4}\right]^{-}$-type species). [ $\left.\mathrm{L}-\mathrm{TiCl}\left(\mathrm{N}(\mathrm{H})\left(\mathrm{C}_{18} \mathrm{H}_{37}\right)_{2}\right)\right]^{+}\left[\mathrm{B}\left(\mathrm{C}_{6} \mathrm{~F}_{5}\right)_{4}\right]^{-}$-type species were also prepared from $5-\mathrm{TiCl}(\mathrm{Me})$ and $6-\mathrm{TiCl}(\mathrm{Me})$, which were newly prepared in this study. The prepared $\left[\mathrm{L}-\mathrm{M}(\mathrm{Me})\left(\mathrm{NMe}\left(\mathrm{C}_{18} \mathrm{H}_{37}\right)_{2}\right)\right]^{+}\left[\mathrm{B}\left(\mathrm{C}_{6} \mathrm{~F}_{5}\right)_{4}\right]^{-}-,\left[\mathrm{L}-\mathrm{Ti}\left(\mathrm{CH}_{2} \mathrm{~N}\left(\mathrm{C}_{18} \mathrm{H}_{37}\right)_{2}\right)\right]^{+}\left[\mathrm{B}\left(\mathrm{C}_{6} \mathrm{~F}_{5}\right)_{4}\right]^{--}$, and $\left[\mathrm{L}-\mathrm{TiCl}\left(\mathrm{N}(\mathrm{H})\left(\mathrm{C}_{18} \mathrm{H}_{37}\right)_{2}\right)\right]^{+}\left[\mathrm{B}\left(\mathrm{C}_{6} \mathrm{~F}_{5}\right)_{4}\right]^{-}$-type species, which are soluble and stable in aliphatic hydrocarbon solvents, were highly active in ethylene/1-octene copolymerization performed in aliphatic hydrocarbon solvents.
\end{abstract}

Keywords: metallocene; half-metallocene; activation reaction; ammonium tetrakis(pentafluorophenyl) borate; olefin polymerization

\section{Introduction}

Since the serendipitous discovery of methylaluminoxane (MAO) by Kaminsky, much effort has been devoted to the synthesis of organometallic complexes to find efficient single-site homogeneous olefin polymerization catalysts, some of which are currently used in the bulk polyolefin industry [1]. The initial metallocene complexes (i.e., $\mathbf{L}-\mathrm{MCl}_{2}$-type complexes, where $\mathrm{L}$ and $\mathrm{M}$ are cyclopentadienyl-type ligands and group-four metals, respectively) have been followed by the development of half-metallocene complexes, in 
which one of the two cyclopentadienyl-type ligands in metallocenes is replaced with an amido or aryloxo ligand, and further by post-metallocene complexes that do not contain any cyclopentadienyl-type ligands [2,3]. The central group-four transition metals have also been expanded to $\mathrm{Ni}, \mathrm{Pd}, \mathrm{Fe}, \mathrm{Co}, \mathrm{Cr}$, and $\mathrm{V}$, especially in post-metallocene complexes [4-7]. Metallocene, half-metallocene, and post-metallocene complexes are not active, and must be activated with a co-catalyst. MAO is a typical example of a co-catalyst used in activation reactions. The structure of $\mathrm{MAO}$ (obtained through partial hydrolysis of $\mathrm{Me}_{3} \mathrm{Al}$ ) is ill-defined, but may be oligomeric $\mathrm{Me}_{2} \mathrm{Al}-[\mathrm{Al}(\mathrm{Me}) \mathrm{O}]_{\mathrm{n}}-\mathrm{AlMe}_{2}$, containing some free $\mathrm{Me}_{3} \mathrm{Al}$, and the mechanism of the activation reaction with $\mathrm{MAO}$ is still elusive [8-10]. In industry, MAOactivated catalysts are used mainly in a slurry or gas phase process after anchoring on the surface of silica particles, where morphological control of the generated polymer particles is crucial [11,12]. MAO is expensive and should be fed in excess relative to organometallic complexes $(\mathrm{Al} / \mathrm{M}>100)$. In a slurry or gas phase process, the catalyst retention time is long $(>1 \mathrm{~h})$ and the productivity of the catalyst can be maximized, mitigating the burden of the catalyst and co-catalyst cost.

Another type of co-catalyst, $\left[\mathrm{PhN}(\mathrm{Me})_{2}-\mathrm{H}\right]^{+}\left[\mathrm{B}\left(\mathrm{C}_{6} \mathrm{~F}_{5}\right)_{4}\right]^{-}$or $\left[\mathrm{Ph}_{3} \mathrm{C}\right]^{+}\left[\mathrm{B}\left(\mathrm{C}_{6} \mathrm{~F}_{5}\right)_{4}\right]^{-}$, was developed for the activation of organometallic complexes, which is used in a solution process in which the catalyst retention time is relatively short $(<20 \mathrm{~min})$ [13-15]. Replacement of excess $\mathrm{MAO}$ with stoichiometric amounts of $\left[\mathrm{B}\left(\mathrm{C}_{6} \mathrm{~F}_{5}\right)_{4}\right]^{-}$-based co-catalyst has also been a crucial issue in the development of Cr-based ethylene tetramerization catalysts [16-18]. In the activation reaction, $\mathrm{L}-\mathrm{M}(\mathrm{Me})_{2}$-type complexes were converted to an ion-pair complex $[\mathrm{L}-\mathrm{M}(\mathrm{Me})]^{+}\left[\mathrm{B}\left(\mathrm{C}_{6} \mathrm{~F}_{5}\right)_{4}\right]^{-}$by the action of the co-catalyst (Scheme 1a-c) [19-21]. [PhN(Me) $2_{2}^{-}$ $\mathrm{H}]^{+}\left[\mathrm{B}\left(\mathrm{C}_{6} \mathrm{~F}_{5}\right)_{4}\right]^{-}$and $\left[\mathrm{Ph}_{3} \mathrm{C}\right]^{+}\left[\mathrm{B}\left(\mathrm{C}_{6} \mathrm{~F}_{5}\right)_{4}\right]^{-}$are well-defined discrete molecules and, conceptually, stoichiometric (equimolar) amounts can be used for the activation reaction, reducing the burden of co-catalyst cost even in a solution process with a short retention time. However, $\left[\mathrm{PhN}(\mathrm{Me})_{2}-\mathrm{H}\right]^{+}\left[\mathrm{B}\left(\mathrm{C}_{6} \mathrm{~F}_{5}\right)_{4}\right]^{-}$and $\left[\mathrm{Ph}_{3} \mathrm{C}\right]^{+}\left[\mathrm{B}\left(\mathrm{C}_{6} \mathrm{~F}_{5}\right)_{4}\right]^{-}$are insoluble in aliphatic hydrocarbon solvents (e.g., hexane, cyclohexane, or methylcyclohexane), in which the commercial solution process of olefin polymerization is performed. The poor solubility of these co-catalysts causes a burden in some cases, and synthesis of the soluble form has been pursued [22-24]. Typically, in order to achieve optimal productivity, an excess amount of $\left[\mathrm{B}\left(\mathrm{C}_{6} \mathrm{~F}_{5}\right)_{4}\right]^{-}$-based co-catalyst ( $>3$ equiv.) should be fed as a slurry phase directly into a bulk polymerization reactor in which both the activation reaction and polymerization reactions take place [25]. After activation in a more polar aromatic hydrocarbon solvent (e.g., toluene), the activated complex may be fed into a reactor filled with aliphatic hydrocarbon solvent. However, $\left[\mathrm{PhN}(\mathrm{Me})_{2}-\mathrm{H}\right]^{+}\left[\mathrm{B}\left(\mathrm{C}_{6} \mathrm{~F}_{5}\right)_{4}\right]^{-}$and $\left[\mathrm{Ph}_{3} \mathrm{C}\right]^{+}\left[\mathrm{B}\left(\mathrm{C}_{6} \mathrm{~F}_{5}\right)_{4}\right]^{-}$are either completely insoluble or sparingly soluble, respectively, in toluene [26], which still requires an excess amount (e.g., 4 equiv.) to achieve optimal productivity [27-29]. For a typical post-metallocene pyridylamido-Hf complex, the activation reaction was thoroughly investigated, and was more complicated than previously thought [30-32]. Trialkylaluminum has been additionally fed into the activation reaction to scrub the impurities and to convert L-MCl ${ }_{2}$-type complexes into $\mathbf{L}-\mathrm{MR}_{2}$, but $\left[\mathrm{Ph}_{3} \mathrm{C}\right]^{+}\left[\mathrm{B}\left(\mathrm{C}_{6} \mathrm{~F}_{5}\right)_{4}\right]^{-}$is destroyed by the action of trialkylaluminum, making the activation reaction more tricky [33].

The best strategy may be the generation of the activated complex in an aliphatic hydrocarbon solvent and feeding of the solution containing the activated species to a bulk aliphatic hydrocarbon polymerization medium. With this aim, a $\left.\left[\mathrm{B}_{(} \mathrm{C}_{6} \mathrm{~F}_{5}\right)_{4}\right]^{-}$-based cocatalyst containing long alkyl chains $\left[\mathrm{Me}\left(\mathrm{C}_{18} \mathrm{H}_{37}\right)_{2} \mathrm{~N}-\mathrm{H}\right]^{+}\left[\mathrm{B}\left(\mathrm{C}_{6} \mathrm{~F}_{5}\right)_{4}\right]^{-}$, which is soluble in cyclohexane or methylcyclohexane, was introduced more than two decades ago by Dow [34]. Activated complexes generated with $\left[\mathrm{Me}\left(\mathrm{C}_{18} \mathrm{H}_{37}\right)_{2} \mathrm{~N}-\mathrm{H}\right]^{+}\left[\mathrm{B}\left(\mathrm{C}_{6} \mathrm{~F}_{5}\right)_{4}\right]^{-}$may be soluble and stable through the coordination of $\mathrm{Me}\left(\mathrm{C}_{18} \mathrm{H}_{37}\right)_{2} \mathrm{~N}$ (a byproduct generated in the activation reaction) with the metal center (i.e., formation of $\left[\mathrm{L}-\mathrm{M}(\mathrm{Me})\left(\mathrm{NMe}\left(\mathrm{C}_{18} \mathrm{H}_{37}\right)_{2}\right)\right]^{+}\left[\mathrm{B}\left(\mathrm{C}_{6} \mathrm{~F}_{5}\right)_{4}\right]^{-}$type species; Scheme 1c) $[35,36]$. However, $\left[\mathrm{Me}\left(\mathrm{C}_{18} \mathrm{H}_{37}\right)_{2} \mathrm{~N}-\mathrm{H}\right]^{+}\left[\mathrm{B}\left(\mathrm{C}_{6} \mathrm{~F}_{5}\right)_{4}\right]^{-}$is highly soluble, cannot be purified by recrystallization, and is contaminated with either water or $\mathrm{Cl}^{-}$ salt impurities, which interfere with the activation reaction [37]. In this work, we report on a method to prepare high-purity trialkylammonium tetrakis(pentafluorophenyl)borate in 
an aliphatic hydrocarbon solvent and the activation reactions of some typical metallocene and half-metallocene complexes.

(a)

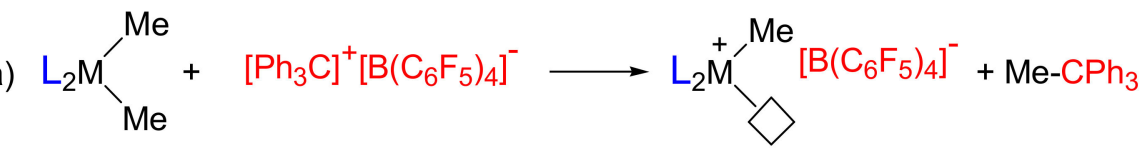

(b)

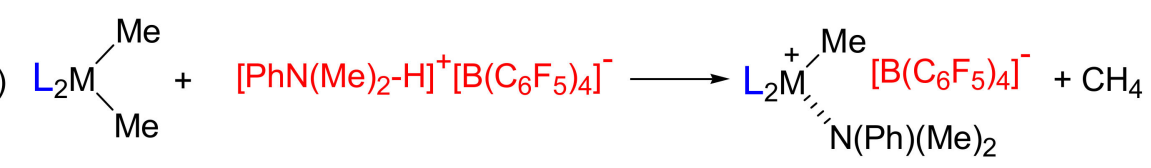

(c)

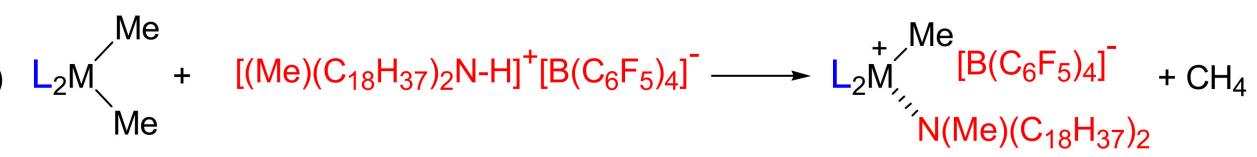

Scheme 1. Activation reactions of organometallic complexes for olefin polymerization with $\left[\mathrm{Ph}_{3} \mathrm{C}\right]^{+}\left[\mathrm{B}\left(\mathrm{C}_{6} \mathrm{~F}_{5}\right)_{4}\right]^{-}($a), $\left[\mathrm{PhN}(\mathrm{Me})_{2}-\mathrm{H}\right]^{+}\left[\mathrm{B}\left(\mathrm{C}_{6} \mathrm{~F}_{5}\right)_{4}\right]^{-}(\mathbf{b})$, and $\left[\mathrm{Me}\left(\mathrm{C}_{18} \mathrm{H}_{37}\right)_{2} \mathrm{~N}-\mathrm{H}\right]^{+}\left[\mathrm{B}\left(\mathrm{C}_{6} \mathrm{~F}_{5}\right)_{4}\right]^{-}$(c).

\section{Results and Discussion}

\subsection{Preparation of $\left[\mathrm{Me}\left(\mathrm{C}_{18} \mathrm{H}_{37}\right)_{2} \mathrm{~N}-\mathrm{H}\right]^{+}\left[\mathrm{B}\left(\mathrm{C}_{6} \mathrm{~F}_{5}\right)_{4}\right]^{-}$}

A preparation method for $\left[\mathrm{Me}\left(\mathrm{C}_{18} \mathrm{H}_{37}\right)_{2} \mathrm{~N}-\mathrm{H}\right]^{+}\left[\mathrm{B}\left(\mathrm{C}_{6} \mathrm{~F}_{5}\right)_{4}\right]^{-}$that uses a salt metathesis reaction between $\mathrm{Li}^{+}\left[\mathrm{B}\left(\mathrm{C}_{6} \mathrm{~F}_{5}\right)_{4}\right]^{-}$and $\left[\mathrm{Me}\left(\mathrm{C}_{18} \mathrm{H}_{37}\right)_{2} \mathrm{~N}-\mathrm{H}\right]^{+}[\mathrm{Cl}]^{-}$(Scheme $2 \mathrm{a}$ ) has been previously reported [34]. In this method, $\mathrm{Li}^{+}\left[\mathrm{B}\left(\mathrm{C}_{6} \mathrm{~F}_{5}\right)_{4}\right]^{-}$and $\left[\mathrm{Me}\left(\mathrm{C}_{18} \mathrm{H}_{37}\right)_{2} \mathrm{~N}-\mathrm{H}\right]^{+}[\mathrm{Cl}]^{-}$were reacted in a toluene/water two-phase, and the product, $\left[\mathrm{Me}\left(\mathrm{C}_{18} \mathrm{H}_{37}\right)_{2} \mathrm{~N}-\mathrm{H}\right]^{+}\left[\mathrm{B}\left(\mathrm{C}_{6} \mathrm{~F}_{5}\right)_{4}\right]^{-}$, was isolated by collecting the toluene phase while discarding the water phase containing the byproduct, $\mathrm{LiCl}$. However, the yield was unsatisfactory $(71 \%)$. Some acidic impurities were concomitantly generated, which were washed out by treatment with $\mathrm{Na}_{2} \mathrm{CO}_{3}$. The $\mathrm{NCH}_{2}$ protons were observed as two broad signals at 1.93 and $1.77 \mathrm{ppm}$ in the ${ }^{1} \mathrm{H}$ NMR spectrum (Figure 1a); the two geminal protons attached to each $\alpha$-methylene carbon (i.e., $\mathrm{NCH}_{2}$ ) are diastereotopic. The $\mathrm{N}-\mathrm{H}$ and $\mathrm{NCH}_{3}$ signals were also broad, not showing a splitting pattern, at 3.4-3.1 ppm and $1.5 \mathrm{ppm}$, respectively. Water impurities might interact with $\mathrm{N}-\mathrm{H}$ and $\alpha$-protons on the ammonium unit $\left(\mathrm{NCH}_{2}\right.$ and $\left.\mathrm{NCH}_{3}\right)$ through hydrogen bonds, causing broadening of the signals. It was impossible to completely remove water impurities; the $\mathrm{NCH}_{2}$ signals were persistently broad even after prolonged evacuation, treatment with desiccants such as molecular sieves, or refluxing toluene solution over the Dean-Stark apparatus. A set of signals assigned to ortho-, para-, and meta-fluorine in the $\left[\mathrm{B}\left(\mathrm{C}_{6} \mathrm{~F}_{5}\right)_{4}\right]^{-}$ion was clearly observed at $-132.22,-161.72$, and $-165.95 \mathrm{ppm}$, respectively, in the ${ }^{19} \mathrm{~F}$ NMR spectrum. $\mathrm{No} \mathrm{Cl}^{-}$anions were detected in the product; treatment of $\left[\left(\mathrm{CH}_{3} \mathrm{CN}\right)_{4} \mathrm{Ag}\right]^{+}\left[\mathrm{B}\left(\mathrm{C}_{6} \mathrm{~F}_{5}\right)_{4}\right]^{-}$with a diethyl ether solution containing the product did not generate any $\mathrm{AgCl}$ precipitates, which indicated that $\mathrm{LiCl}$ was thoroughly removed by washing with water (Supplementary Materials Figure S1b). 
(a) $\mathrm{M}^{+}\left[\mathrm{B}\left(\mathrm{C}_{6} \mathrm{~F}_{5}\right)_{4}\right]^{-}+\left[\mathrm{Me}\left(\mathrm{C}_{18} \mathrm{H}_{37}\right)_{2} \mathrm{~N}-\mathrm{H}\right]^{+} \mathrm{Cl}^{-} \longrightarrow\left[\mathrm{Me}\left(\mathrm{C}_{18} \mathrm{H}_{37}\right)_{2} \mathrm{~N}-\mathrm{H}\right]^{+}\left[\mathrm{B}\left(\mathrm{C}_{6} \mathrm{~F}_{5}\right)_{4}\right]^{-}+\mathrm{M}^{+} \mathrm{Cl}^{-}$ $(\mathrm{M}=\mathrm{Li}$ or $\mathrm{K})$

(b) $\left[\mathrm{PhN}(\mathrm{Me})_{2}-\mathrm{H}\right]^{+}\left[\mathrm{B}\left(\mathrm{C}_{6} \mathrm{~F}_{5}\right)_{4}\right]^{-}+\mathrm{Me}\left(\mathrm{C}_{18} \mathrm{H}_{37}\right)_{2} \mathrm{~N} \longrightarrow\left[\mathrm{Me}\left(\mathrm{C}_{18} \mathrm{H}_{37}\right)_{2} \mathrm{~N}-\mathrm{H}\right]^{+}\left[\mathrm{B}\left(\mathrm{C}_{6} \mathrm{~F}_{5}\right)_{4}\right]^{-}+\mathrm{PhN}(\mathrm{Me})_{2}$

$$
\mathrm{pK}_{\mathrm{a}, \sim 5} \quad\left\{\begin{array}{l}
\left(\mathrm{C}_{12} \mathrm{H}_{25}\right)_{3} \mathrm{~N} \\
\left(\mathrm{C}_{8} \mathrm{H}_{17}\right)_{3} \mathrm{~N} \\
\left(\mathrm{C}_{18} \mathrm{H}_{37}\right)_{2} \mathrm{NH} \\
\mathrm{pK}_{\mathrm{a}}, \sim 10
\end{array}\right\} \quad\left\{\begin{array}{l}
{\left[\left(\mathrm{C}_{12} \mathrm{H}_{25}\right)_{3} \mathrm{~N}-\mathrm{H}\right]^{+}\left[\mathrm{B}\left(\mathrm{C}_{6} \mathrm{~F}_{5}\right)_{4}\right]^{-}} \\
{\left[\left(\mathrm{C}_{8} \mathrm{H}_{17}\right)_{3} \mathrm{~N}-\mathrm{H}\right]^{+}\left[\mathrm{B}\left(\mathrm{C}_{6} \mathrm{~F}_{5}\right)_{4}\right]^{-}} \\
{\left[\left(\mathrm{C}_{18} \mathrm{H}_{37}\right)_{2} \mathrm{NH}_{2}\right]^{+}\left[\mathrm{B}\left(\mathrm{C}_{6} \mathrm{~F}_{5}\right)_{4}\right]^{-}}
\end{array}\right\}
$$

Scheme 2. Preparation of $\left[\mathrm{Me}\left(\mathrm{C}_{18} \mathrm{H}_{37}\right)_{2} \mathrm{~N}-\mathrm{H}\right]^{+}\left[\mathrm{B}\left(\mathrm{C}_{6} \mathrm{~F}_{5}\right)_{4}\right]^{-}$via the conventional salt metathesis reaction (a) and via the acid-base reaction disclosed in this work $(\mathbf{b})$.

(a)
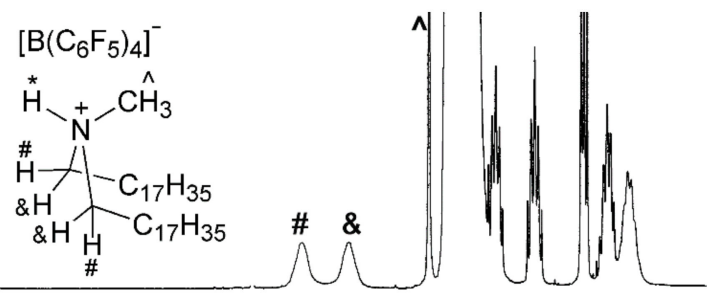

(b)
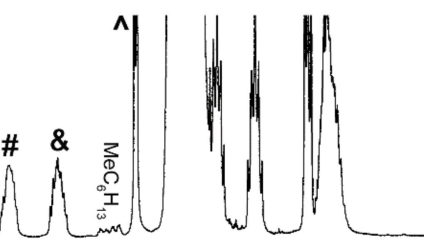

(c)
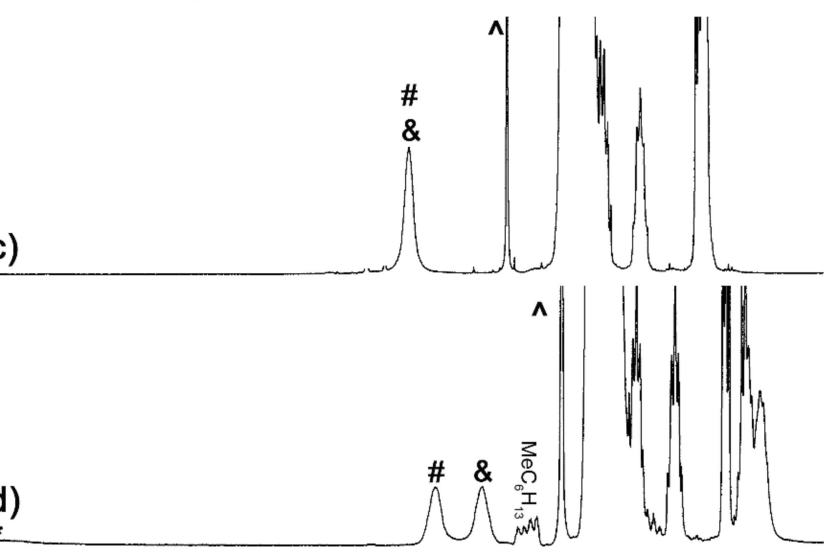

(d)
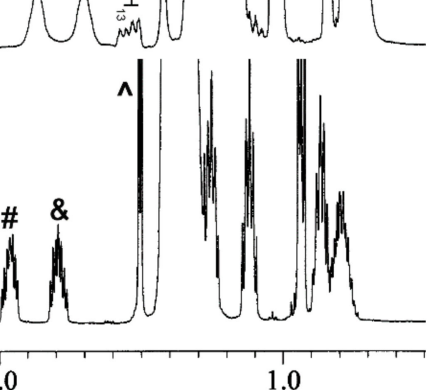

$$
\text { (e) }
$$

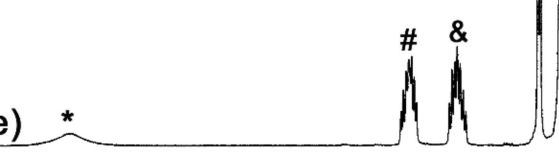

2.0

Figure 1. ${ }^{1} \mathrm{H}$ NMR spectra (recorded in $\left.\mathrm{C}_{6} \mathrm{D}_{6}\right)$ of $\left[\mathrm{Me}\left(\mathrm{C}_{18} \mathrm{H}_{37}\right)_{2} \mathrm{~N}-\mathrm{H}\right]^{+}\left[\mathrm{B}\left(\mathrm{C}_{6} \mathrm{~F}_{5}\right)_{4}\right]^{-}$prepared by the reactions $\mathrm{Li}^{+}\left[\mathrm{B}\left(\mathrm{C}_{6} \mathrm{~F}_{5}\right)_{4}\right]^{-}+\left[\mathrm{Me}\left(\mathrm{C}_{18} \mathrm{H}_{37}\right)_{2} \mathrm{~N}-\mathrm{H}\right]^{+}[\mathrm{Cl}]^{-}$(removal of $\mathrm{LiCl}$ with water) $(\mathbf{a}), \mathrm{Li}^{+}\left[\mathrm{B}\left(\mathrm{C}_{6} \mathrm{~F}_{5}\right)_{4}\right]^{-}$ $+\left[\mathrm{Me}\left(\mathrm{C}_{18} \mathrm{H}_{37}\right)_{2} \mathrm{~N}-\mathrm{H}\right]^{+}[\mathrm{Cl}]^{-}$(removal of $\mathrm{LiCl}$ by filtration) $(\mathbf{b}), \mathrm{K}^{+}\left[\mathrm{B}\left(\mathrm{C}_{6} \mathrm{~F}_{5}\right)_{4}\right]^{-}+\left[\mathrm{Me}\left(\mathrm{C}_{18} \mathrm{H}_{37}\right)_{2} \mathrm{~N}-\right.$ $\mathrm{H}]^{+}[\mathrm{Cl}]^{-}$(removal of $\mathrm{KCl}$ with water) $(\mathrm{c}), \mathrm{K}^{+}\left[\mathrm{B}\left(\mathrm{C}_{6} \mathrm{~F}_{5}\right)_{4}\right]^{-}+\left[\mathrm{Me}\left(\mathrm{C}_{18} \mathrm{H}_{37}\right)_{2} \mathrm{~N}-\mathrm{H}\right]^{+}[\mathrm{Cl}]^{-}$(removal of $\mathrm{KCl}$ by filtration) (d), and $\left[\mathrm{PhN}(\mathrm{Me})_{2}-\mathrm{H}\right]^{+}\left[\mathrm{B}\left(\mathrm{C}_{6} \mathrm{~F}_{5}\right)_{4}\right]^{-}+\mathrm{Me}\left(\mathrm{C}_{18} \mathrm{H}_{37}\right)_{2} \mathrm{~N}(\mathbf{e})$. Signals marked with *, \#, $\&$, and ${ }^{\wedge}$ characters correspond to protons marked with those characters in the structure. 
The byproduct $\mathrm{LiCl}$ can also be removed by filtration [38]. The product $\left[\mathrm{Me}\left(\mathrm{C}_{18} \mathrm{H}_{37}\right)_{2} \mathrm{~N}-\right.$ $\mathrm{H}]^{+}\left[\mathrm{B}\left(\mathrm{C}_{6} \mathrm{~F}_{5}\right)_{4}\right]^{-}$is soluble in aliphatic hydrocarbon solvents, such as cyclohexane or methylcyclohexane, while $\mathrm{LiCl}$ is insoluble, enabling the removal of $\mathrm{LiCl}$ by filtration after performing a metathesis reaction in methylcyclohexane. The yield was satisfactorily high (94\%), but the filtration procedure was tedious; the $\mathrm{LiCl}$ particles generated were so fine they clogged and even penetrated the Celite pad. Filtration was repeated several times, using a thick Celite pad to obtain a clear solution. In the ${ }^{1} \mathrm{H}$ NMR spectrum, the $\mathrm{NCH}_{2}$ signals were fairly sharp, showing a splitting pattern, but the N-H signal was absent, possibly due to broadening (Figure $1 \mathrm{~b}$ ). Treatment of $\left[\left(\mathrm{CH}_{3} \mathrm{CN}\right)_{4} \mathrm{Ag}\right]^{+}\left[\mathrm{B}\left(\mathrm{C}_{6} \mathrm{~F}_{5}\right)_{4}\right]^{-}$with a solution containing the product changed the clear solution turbid due to the formation of $\mathrm{AgCl}$ particles (Supplementary Materials Figure S1c), which indicated that the product was contaminated with $\mathrm{Cl}^{-}$ions.

Attempts to prepare $\left[\mathrm{Me}\left(\mathrm{C}_{18} \mathrm{H}_{37}\right)_{2} \mathrm{~N}-\mathrm{H}\right]^{+}\left[\mathrm{B}\left(\mathrm{C}_{6} \mathrm{~F}_{5}\right)_{4}\right]^{-}$by using another commercial source of borate salt, $\mathrm{K}^{+}\left[\mathrm{B}\left(\mathrm{C}_{6} \mathrm{~F}_{5}\right)_{4}\right]^{-}$, gave similar results. In the salt metathesis reaction performed in two water/toluene phases, the yield was low (74\%) and the product was contaminated with water, although the $\mathrm{Ag}^{+}$test indicated the absence of $\mathrm{Cl}^{-}$anions (Supplementary Materials Figure S1d). Owing to the presence of water impurities, the two diastereotopic $\mathrm{NCH}_{2}$ signals collapsed into a single broad signal (Figure 1c). In the salt metathesis reaction performed in anhydrous methylcyclohexane, the filtration procedure was also tedious, requiring several rounds of filtration to obtain a clear solution, and the product was contaminated with $\mathrm{Cl}^{-}$anions (Supplementary Materials Figure S1e). Two signals were observed for the diastereotopic $\mathrm{NCH}_{2}$ protons, but they were broad and did not show any splitting pattern, which was indicative of water contamination in the resulting product (Figure $1 \mathrm{~d}$ ). The commercial source of $\mathrm{K}^{+}\left[\mathrm{B}\left(\mathrm{C}_{6} \mathrm{~F}_{5}\right)_{4}\right]^{-}$contained some amount of water impurities, which eventually caused water contamination in the product $\left[\mathrm{Me}\left(\mathrm{C}_{18} \mathrm{H}_{37}\right)_{2} \mathrm{~N}-\mathrm{H}\right]^{+}\left[\mathrm{B}\left(\mathrm{C}_{6} \mathrm{~F}_{5}\right)_{4}\right]^{-}$.

N,N-Dimethylanilinium tetrakis(pentafluorophenyl)borate $\left(\left[\mathrm{PhN}(\mathrm{Me})_{2}-\mathrm{H}\right]^{+}\left[\mathrm{B}\left(\mathrm{C}_{6} \mathrm{~F}_{5}\right)_{4}\right]^{-}\right)$ is the chemical most frequently used in commercial processes on a large scale. Although it is prepared via the salt metathesis reaction of $\mathrm{M}^{+}\left[\mathrm{B}\left(\mathrm{C}_{6} \mathrm{~F}_{5}\right)_{4}\right]^{-}(\mathrm{M}=\mathrm{Li}, \mathrm{K})$ and $\left[\mathrm{PhN}(\mathrm{Me})_{2}{ }^{-}\right.$ $\mathrm{H}^{+} \mathrm{Cl}^{-}$[38,39], it can be purified via recrystallization and is available on a large scale as a high-purity crystalline solid. In contrast, $\left[\mathrm{Me}\left(\mathrm{C}_{18} \mathrm{H}_{37}\right)_{2} \mathrm{~N}-\mathrm{H}\right]^{+}\left[\mathrm{B}\left(\mathrm{C}_{6} \mathrm{~F}_{5}\right)_{4}\right]^{-}$is highly soluble, and there is no purification method. We designed another method to prepare high-purity $\left[\mathrm{Me}\left(\mathrm{C}_{18} \mathrm{H}_{37}\right)_{2} \mathrm{~N}-\mathrm{H}\right]^{+}\left[\mathrm{B}\left(\mathrm{C}_{6} \mathrm{~F}_{5}\right)_{4}\right]^{-}$from $\left[\mathrm{PhN}(\mathrm{Me})_{2}-\mathrm{H}\right]^{+}\left[\mathrm{B}\left(\mathrm{C}_{6} \mathrm{~F}_{5}\right)_{4}\right]^{-}$, in which an acid-base reaction was employed instead of the tedious salt metathesis reaction (Scheme $2 \mathrm{~b}$ ). The $\mathrm{pK}_{\mathrm{a}}$ value of the aniline/anilinium Brønsted base-acid pair is approximately 5, while that of the trialkylammonium/trialkylamine Brønsted acid-base pair is approximately 10, and $\left[\mathrm{PhN}(\mathrm{Me})_{2}-\mathrm{H}\right]^{+}\left[\mathrm{B}\left(\mathrm{C}_{6} \mathrm{~F}_{5}\right)_{4}\right]^{-}$could be converted to $\left[\mathrm{Me}\left(\mathrm{C}_{18} \mathrm{H}_{37}\right)_{2} \mathrm{~N}-\mathrm{H}\right]^{+}\left[\mathrm{B}\left(\mathrm{C}_{6} \mathrm{~F}_{5}\right)_{4}\right]^{-}$by treatment with $\mathrm{Me}\left(\mathrm{C}_{18} \mathrm{H}_{37}\right)_{2} \mathrm{~N}$ in toluene (equilibrium constant anticipated $=10^{\triangle \mathrm{pKa}}$, i.e., $\sim 10^{5}$ ). The byproduct in this reaction was a neutral compound, $\mathrm{PhN}(\mathrm{Me})_{2}$ (boiling point, $194{ }^{\circ} \mathrm{C}$ ), which could be simply and completely removed by evacuation at $50-60^{\circ} \mathrm{C}$. In this method, it was impossible for the product to be contaminated with $\mathrm{Cl}^{-}$and water once anhydrous reagents and solvents were used. The yield was quantitative, and no $\mathrm{Cl}^{-}$ions were detected in the $\mathrm{Ag}^{+}$test (Supplementary Materials Figure S1a). In the ${ }^{1} \mathrm{H} \mathrm{NMR}$ spectrum, the $\mathrm{NCH}_{2}$ and $\mathrm{NCH}_{3}$ signals were observed to be well split (Figure 1e). When water was deliberately added, the well-split $\mathrm{NCH}_{2}$ signals were broadened as observed in Figure 1d, inferring that water contamination was a cause of signal broadening (Supplementary Materials Figure S2). Employing the same synthetic protocol, $\left[\left(\mathrm{C}_{12} \mathrm{H}_{25}\right)_{3} \mathrm{~N}-\mathrm{H}\right]^{+}\left[\mathrm{B}\left(\mathrm{C}_{6} \mathrm{~F}_{5}\right)_{4}\right]^{-}$and $\left[\left(\mathrm{C}_{8} \mathrm{H}_{17}\right)_{3} \mathrm{~N}-\mathrm{H}\right]^{+}\left[\mathrm{B}\left(\mathrm{C}_{6} \mathrm{~F}_{5}\right)_{4}\right]^{-}$were successfully prepared by using $\left(\mathrm{C}_{12} \mathrm{H}_{25}\right)_{3} \mathrm{~N}$ and $\left(\mathrm{C}_{8} \mathrm{H}_{17}\right)_{3} \mathrm{~N}$ instead of $\mathrm{Me}\left(\mathrm{C}_{18} \mathrm{H}_{37}\right)_{2} \mathrm{~N}$ (Scheme 2b; Supplementary Materials Figure S3). The former was soluble in methylcyclohexane, whereas the latter was not. The secondary amine-derived $\left[\left(\mathrm{C}_{18} \mathrm{H}_{37}\right)_{2} \mathrm{NH}_{2}\right]^{+}\left[\mathrm{B}\left(\mathrm{C}_{6} \mathrm{~F}_{5}\right)_{4}\right]^{-}$, which is soluble in methylcyclohexane, was also obtained by using the same synthetic protocol (Supplementary Materials Figure S4), whereas primary amines such as $\left(\mathrm{C}_{17} \mathrm{H}_{35}\right)_{2} \mathrm{C}(\mathrm{H}) \mathrm{NH}_{2}$ were not effective in the synthetic protocol. 


\subsection{Preparation of $L-M(M e)_{2}$ and $L-M C l(M e)$-Type Complexes for Activation Studies}

In most cases in industry, as well as in the laboratory, olefin polymerizations have been performed with in situ-generated activated species with neither isolation of the activated species nor monitoring of the activation reaction, because the activated species (i.e., ion pair complexes) are, in most cases, unstable or insoluble in hydrocarbon solvents. In this work, NMR spectroscopy was used to monitor the activation reactions of commercial process-relevant metallocene and half-metallocene complexes (Scheme 3) with the prepared high-purity $\left[\mathrm{Me}\left(\mathrm{C}_{18} \mathrm{H}_{37}\right)_{2} \mathrm{~N}-\mathrm{H}\right]^{+}\left[\mathrm{B}\left(\mathrm{C}_{6} \mathrm{~F}_{5}\right)_{4}\right]^{-}$, which did not contain any water or $\mathrm{Cl}^{-}$impurities. Complexes rac-[ethylenebis(tetrahydroindenyl)] $\mathrm{Zr}(\mathrm{Me})_{2}$ $\left(1-\mathrm{ZrMe}_{2}\right)$ and rac-[ethylenebis(indenyl)] $\mathrm{Zr}(\mathrm{Me})_{2}\left(2-\mathrm{ZrMe}_{2}\right)$ are a representative among metallocene complexes. Hafnocene complexes $\left[\mathrm{Ph}_{2} \mathrm{C}(\mathrm{Cp})\left(3,6-{ }^{t} \mathrm{Bu}_{2} \mathrm{Flu}\right)\right] \mathrm{Hf}(\mathrm{Me})_{2}\left(3-\mathrm{HfMe}_{2}\right)$ and $\left[\mathrm{Ph}_{2} \mathrm{C}(\mathrm{Cp})\left(2,7-{ }^{t} \mathrm{Bu}_{2} \mathrm{Flu}\right)\right] \mathrm{Hf}(\mathrm{Me})_{2}\left(4-\mathrm{HfMe}_{2}\right)$ were prepared in this work. $\mathrm{L}-\mathrm{MCl}_{2}$-type complexes are the most common source of olefin polymerization catalyst precursors, which have been conventionally converted to $\mathrm{L}-\mathrm{M}(\mathrm{Me})_{2}$-type complexes by the action of MeLi or $\mathrm{MeMgCl}$. Although 3- $-\mathrm{HfMe}_{2}$ and 4- $-\mathrm{HfMe}_{2}$ could be prepared via the conventional method (i.e., reacting $\mathrm{L}-\mathrm{MCl}_{2}$-type complexes with $\mathrm{MeMgCl}$ ), they were prepared in a more facile and direct manner from ligand precursors $3-\mathrm{Li}_{2}$ and $4-\mathrm{Li}_{2}$ in one pot; they gave a moderate yield $(41 \%)$ when $3-\mathrm{Li}_{2}$ and $4-\mathrm{Li}_{2}$ were treated with $\mathrm{HfCl}_{4}$ in the presence of two equivalents of $\mathrm{MeMgBr}$ [40]. The structure of $4-\mathrm{HfMe}_{2}$ was confirmed by X-ray crystallography, as shown in Figure 2.

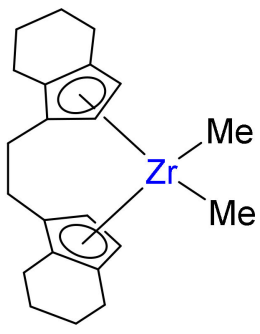

$1-\mathrm{ZrMe}_{2}$

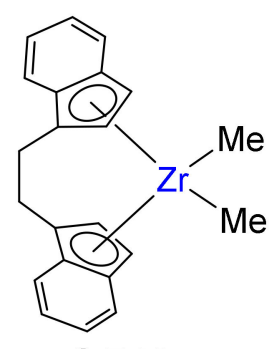

$2-\mathrm{ZrMe}_{2}$

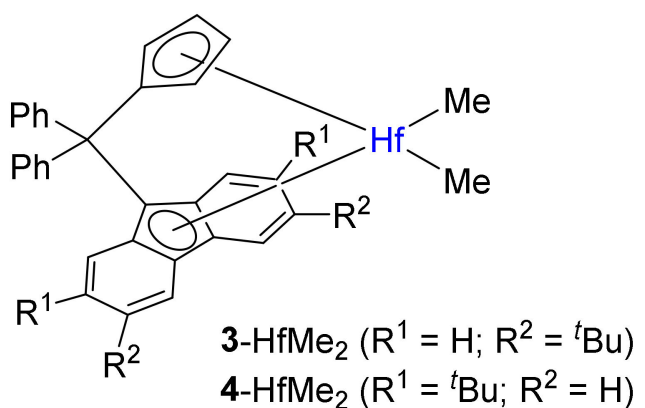<smiles>CC(C)=C(C)C(C)C</smiles>

5- $\mathrm{TiMe}_{2}$<smiles>Cc1c(C)c2c3c(cccc3c1C)CCCN2[In](C)C</smiles>

6- $\mathrm{TiMe}_{2}$<smiles></smiles>

7-TiMe

Scheme 3. Metallocene and half-metallocene complexes studied in the activation and polymerization reactions. 


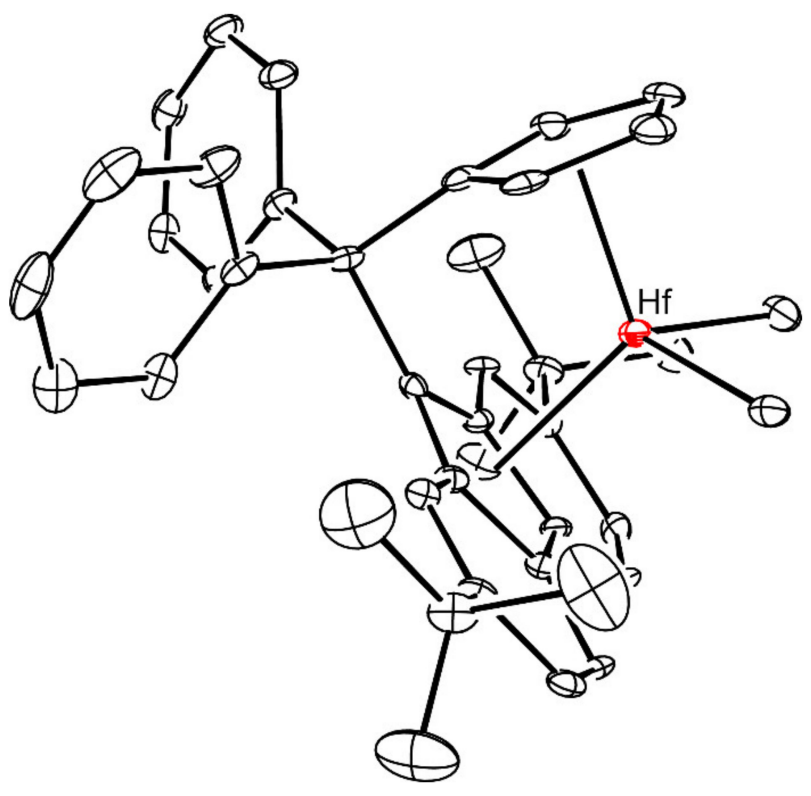

Figure 2. Structure of $4-\mathrm{HfMe}_{2}$ revealed by X-ray crystallography.

Complex $\left[\left(\eta^{5}-\mathrm{Me}_{4} \mathrm{C}_{5}\right) \mathrm{Si}(\mathrm{Me})_{2}\left(\mathrm{k}-\mathrm{N}^{\mathrm{t}} \mathrm{Bu}\right)\right] \mathrm{Ti}(\mathrm{Me})_{2}\left(5-\mathrm{TiMe}_{2}\right)$ is a representative among half-metallocene complexes, named CGC (Constrained Geometry Complex), and tetrahydro quinoline- derived half-metallocene complex $\left[\left(\eta^{5}-\mathrm{Me}_{4} \mathrm{C}_{5}\right)\left(\mathrm{C}_{9} \mathrm{H}_{9}(\kappa-\mathrm{N})\right)\right] \mathrm{Ti}(\mathrm{Me})_{2}$ (6$\left.\mathrm{TiMe}_{2}\right)$ and thiophene-fused cyclopentadienyl Ti complex $\left[\left(\eta^{5}-\mathrm{Me}_{3} \mathrm{C}_{7} \mathrm{H}_{1} \mathrm{~S}\right)\left(\mathrm{C}_{10} \mathrm{H}_{11}(\mathrm{k}-\mathrm{N})\right)\right]$ $\mathrm{Ti}(\mathrm{Me})_{2}\left(7-\mathrm{TiMe}_{2}\right)$ are the ones developed in our laboratory. Half-metallocene complexes 5-TiMe $2,6-\mathrm{TiMe}_{2}$, and 7-TiMe 2 were also obtained in good yields when $\mathbf{L}-\mathrm{Li}_{2}$ or $\mathbf{L}-(\mathrm{MgCl})_{2}$ were treated with $\mathrm{TiCl}_{4}$ in the presence of two equivalents of $\mathrm{MeMgCl}$ [41-44]. It was attempted to prepare $\mathrm{L}-\mathrm{MCl}(\mathrm{Me})$-type complexes. When $6-(\mathrm{MgCl})_{2}$ was treated with $\mathrm{TiCl}_{4}(\mathrm{DME})$ in the presence of one equivalent of $\mathrm{MeMgCl}$ with the aim of obtaining 6$\mathrm{TiCl}(\mathrm{Me})$, the desired complex was generated but contaminated with a significant amount of 6-TiMe 2 (1:2.5). The desired 6-TiCl(Me) complex was cleanly generated when 6- $\mathrm{TiMe}_{2}$ was treated with a half equivalent $\mathrm{ZnCl}_{2}$ in toluene or $\mathrm{C}_{6} \mathrm{D}_{6}$ (Scheme $4 \mathrm{a}$; Supplementary Materials Figure S5). The byproduct $\mathrm{Me}_{2} \mathrm{Zn}$ signal was observed at $-0.68 \mathrm{ppm}$, which could be removed during the solvent removal step (boiling point of $\mathrm{Me}_{2} \mathrm{Zn}, 46^{\circ} \mathrm{C}$ ). Complex 6- $\mathrm{TiCl}(\mathrm{Me})$ was stable in $\mathrm{C}_{6} \mathrm{D}_{12}$, that is, the disproportionation of 6- $\mathrm{TiCl}(\mathrm{Me})$ to $6-\mathrm{TiMe}_{2}$ and 6- $\mathrm{TiCl}_{2}$ species did not occur in $\mathrm{C}_{6} \mathrm{D}_{12}$. Complex 5-TiCl(Me) was also prepared by using the same method. ${ }^{1} \mathrm{H}$ and ${ }^{13} \mathrm{C}$ NMR spectra agreed with the structure (Supplementary Materials Figure S5), and the structures of $5-\mathrm{TiCl}(\mathrm{Me})$ and $\mathbf{6}-\mathrm{TiCl}(\mathrm{Me})$ were confirmed by X-ray crystallography, although the $\mathrm{TiCl}(\mathrm{Me})$ fragments were disordered (Figure 3). L-TiCl 2 -type half-metallocene complexes (e.g., $5-\mathrm{TiCl}_{2}$ and $6-\mathrm{TiCl}_{2}$ ) are not yielded when $\mathbf{L}-\mathrm{Li}_{2}$ or $\mathbf{L}-(\mathrm{MgCl})_{2}$ was reacted directly with $\mathrm{TiCl}_{4}$, although the corresponding reaction in the presence of two equivalents of $\mathrm{MeMgCl}$ afforded the $\mathbf{L}$-TiMe $\mathrm{T}_{2}$-type complexes in good yields. Reported preparation method for $5-\mathrm{TiCl}_{2}$ was a tedious and costly two-step process: reacting $5-\mathrm{Li}_{2}$ with $\mathrm{TiCl}_{3}(\mathrm{THF})_{2}$ to obtain $5-\mathrm{Ti}^{\mathrm{III}} \mathrm{Cl}$, which was transformed to $5-\mathrm{TiCl}_{2}$ by treatment with $\mathrm{PbCl}_{2}$ or $\mathrm{AgCl}$ [45]. Preparation of $6-\mathrm{TiCl}_{2}$ was not reported yet. In this work, it was also demonstrated that 5-TiMe 2 and 6- $\mathrm{TiMe}_{2}$ could be easily transformed to 5- $-\mathrm{TiCl}_{2}$ and 6- $\mathrm{TiCl}_{2}$, respectively, through the treatment of an equimolar amount of $\mathrm{ZnCl}_{2}$ (Scheme $4 b$; Supplementary Materials Figure S6). 
(a) $\mathrm{L}^{-\mathrm{TiMe}_{2}}+1 / 2 \mathrm{ZnCl}_{2} \longrightarrow \mathrm{L}-\mathrm{TiCl}(\mathrm{Me})$<smiles>CC(C)=C(C)C(C)(C)C</smiles>

Scheme 4. Preparation of $\mathrm{L}-\mathrm{TiCl}(\mathrm{Me})$ (a) and $\mathrm{L}-\mathrm{TiCl}_{2}$ (b) types half-metallocene complexes.
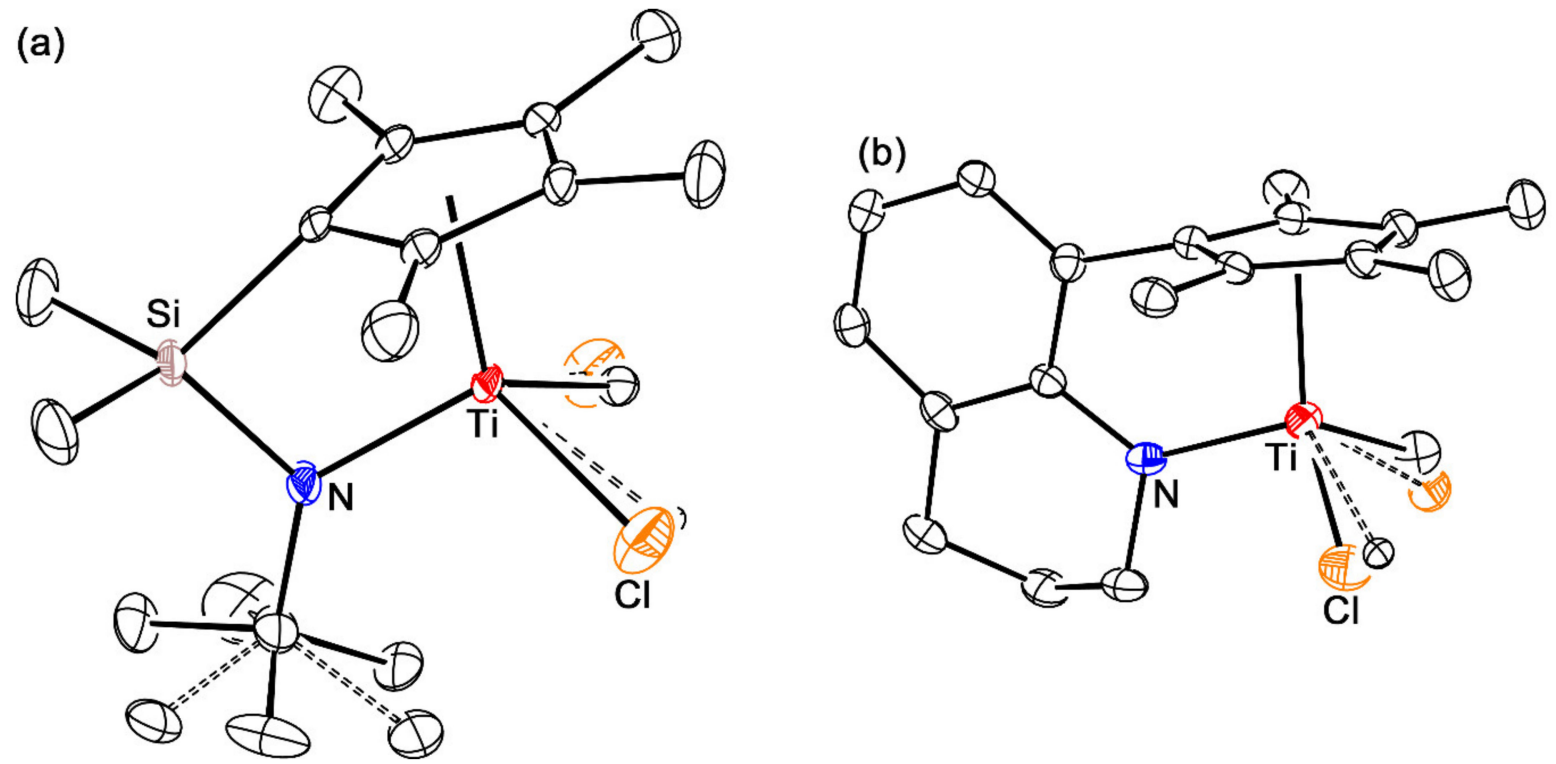

Figure 3. Structures of 5- $\mathrm{TiCl}(\mathrm{Me})(\mathbf{a})$ and $6-\mathrm{TiCl}(\mathrm{Me})(\mathbf{b})$ revealed by X-ray crystallography.

\subsection{Activation Reactions}

In the activation reaction of $1-\mathrm{ZrMe}_{2}$ with $\left[\mathrm{Me}\left(\mathrm{C}_{18} \mathrm{H}_{37}\right)_{2} \mathrm{~N}-\mathrm{H}\right]^{+}\left[\mathrm{B}\left(\mathrm{C}_{6} \mathrm{~F}_{5}\right)_{4}\right]^{-}$, performed with the aromatic hydrocarbon solvent $\mathrm{C}_{6} \mathrm{D}_{6}$ in a sealed NMR tube, the ${ }^{1} \mathrm{H}$ NMR spectral signals assigned to $1-\mathrm{ZrMe}_{2}$ completely disappeared with the generation of methane, but the generated signals were too complicated to be assigned to a single species. However, when the reaction was performed in the aliphatic hydrocarbon solvent $C_{6} D_{12}$, a set of signals that could be assigned to the desired activated ion pair complex, $\left[1-\mathrm{Zr}(\mathrm{Me})\left(\mathrm{NMe}\left(\mathrm{C}_{18} \mathrm{H}_{37}\right)_{2}\right)\right]^{+}$ $\left[\mathrm{B}\left(\mathrm{C}_{6} \mathrm{~F}_{5}\right)_{4}\right]^{-}$, was cleanly generated with a methane signal (Figure 4$)$. The byproduct amine $\mathrm{Me}\left(\mathrm{C}_{18} \mathrm{H}_{37}\right)_{2} \mathrm{~N}$ might loosely coordinate to the cationic $\mathrm{Zr}$ center, making the signals relatively broad. By coordination with $\mathrm{Me}\left(\mathrm{C}_{18} \mathrm{H}_{37}\right)_{2} \mathrm{~N}$, the two indenyl moieties are inequivalent, leading to the observation of four indenyl protons and carbons separately at 5.97, 5.91, 5.68, and $5.55 \mathrm{ppm}$ as a broad singlet in the ${ }^{1} \mathrm{H}$ NMR spectrum (Figure $4 \mathrm{~b}$ and Supplementary Materials Figure S7) and 115.8, 114.8, 113.0, and $109.2 \mathrm{ppm}$ in ${ }^{13} \mathrm{C}$ NMR spectrum (Supplementary Materials Figures S8 and S9). Signal for $\mathrm{Zr}-\mathrm{CH}_{3}$ was observed at $0.73 \mathrm{ppm}$ as a singlet in the ${ }^{1} \mathrm{H}$ NMR spectrum and at $45.7 \mathrm{ppm}$ in the ${ }^{13} \mathrm{C}$ NMR spectrum. In the ${ }^{19} \mathrm{~F}$ NMR spectrum, a set of clean signals assignable to ortho-, para-, and meta-fluorine of $-\mathrm{C}_{6} \mathrm{~F}_{5}$ were observed at $-132.0,-163.6$, and $-167.2 \mathrm{ppm}$ (Supplementary Materials Figure S10), indicating that the $\left[\mathrm{B}\left(\mathrm{C}_{6} \mathrm{~F}_{5}\right)_{4}\right]^{-}$anion was not destroyed during the activation reaction. The activated complex was stable in $\mathrm{C}_{6} \mathrm{D}_{12}$; the signals assigned to $\left[1-\mathrm{Zr}(\mathrm{Me})\left(\mathrm{N}(\mathrm{Me})\left(\mathrm{C}_{18} \mathrm{H}_{37}\right)_{2}\right)\right]^{+}\left[\mathrm{B}\left(\mathrm{C}_{6} \mathrm{~F}_{5}\right)_{4}\right]^{-}$were persistently observed with no generation of other signals, even after a week. In contrast, many unidentified solids were deposited in the reaction of $2-Z_{r M e}$. In the $\mathrm{C}_{6} \mathrm{D}_{12}$ solution phase, the signals that were assigned to the desired $\left[2-\mathrm{Zr}(\mathrm{Me})\left(\mathrm{NMe}\left(\mathrm{C}_{18} \mathrm{H}_{37}\right)_{2}\right)\right]^{+}\left[\mathrm{B}\left(\mathrm{C}_{6} \mathrm{~F}_{5}\right)_{4}\right]^{-}$ 
were observed at the initial stage, but disappeared overnight along with the complicated signals that could not be interpreted.

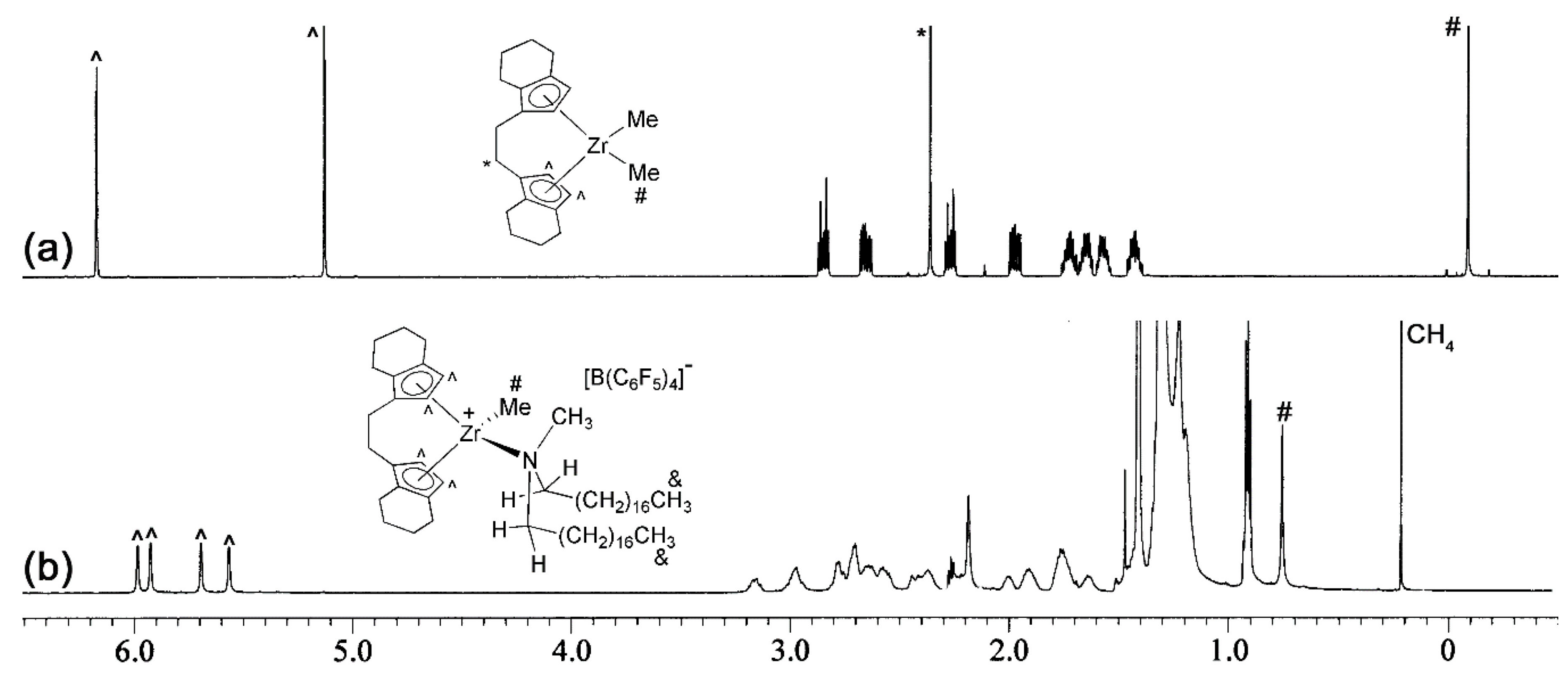

Figure 4. ${ }^{1} \mathrm{H}$ NMR spectra of $1-\mathrm{ZrMe}_{2}$ (a) and its activated complex $\left[1-\mathrm{Zr}(\mathrm{Me})\left(\mathrm{N}(\mathrm{Me})\left(\mathrm{C}_{18} \mathrm{H}_{37}\right)_{2}\right)\right]^{+}\left[\mathrm{B}\left(\mathrm{C}_{6} \mathrm{~F}_{5}\right)_{4}\right]^{-}(\mathbf{b})$. Signals marked with ${ }^{*}$, , and \# characters correspond to protons marked with those characters in the structure.

When 3-HfMe 2 was reacted with $\left[\mathrm{Me}\left(\mathrm{C}_{18} \mathrm{H}_{37}\right)_{2} \mathrm{~N}-\mathrm{H}\right]^{+}\left[\mathrm{B}\left(\mathrm{C}_{6} \mathrm{~F}_{5}\right)_{4}\right]^{-}$in $\mathrm{C}_{6} \mathrm{D}_{12}$, analysis of the ${ }^{1} \mathrm{H}$ NMR spectrum indicated that the desired ion-pair complex [3- $\left.\mathrm{Hf}(\mathrm{Me})\left(\mathrm{NMe}\left(\mathrm{C}_{18} \mathrm{H}_{37}\right)_{2}\right)\right]^{+}$ $\left[\mathrm{B}\left(\mathrm{C}_{6} \mathrm{~F}_{5}\right)_{4}\right]^{-}$was cleanly generated (Figure 5). Owing to the coordination of $\mathrm{Me}\left(\mathrm{C}_{18} \mathrm{H}_{37}\right)_{2} \mathrm{~N}$ with a vacant site of the $\mathrm{Hf}$ center, four cyclopentadienyl protons and six fluorenyl protons were independently observed. Signals corresponding to $\mathrm{NCH}_{3}$ and $\mathrm{NCH}_{2}$ were very broad at $1.89-2.93 \mathrm{ppm}$, indicating that $\mathrm{Me}\left(\mathrm{C}_{18} \mathrm{H}_{37}\right)_{2} \mathrm{~N}$ loosely interacts with the Hf center; $\mathrm{Me}\left(\mathrm{C}_{18} \mathrm{H}_{37}\right)_{2} \mathrm{~N}$ might be under fluxional between a coordinated state and an uncoordinated state while occurring the site epimerization. For free $\mathrm{Me}\left(\mathrm{C}_{18} \mathrm{H}_{37}\right)_{2} \mathrm{~N}$, signals corresponding to $\mathrm{NCH}_{3}$ and $\mathrm{NCH}_{2}$ were observed in the same region (2.10 and $2.23 \mathrm{ppm}$ ) as singlet and triplet, respectively (Supplementary Materials Figure S11). The activated complex was stable as a solution in $\mathrm{C}_{6} \mathrm{D}_{12}$; the ${ }^{1} \mathrm{H}$ NMR spectrum was unaltered when recorded after several weeks. Analysis of the ${ }^{1} \mathrm{H}$ NMR spectrum indicated that the desired ion-pair complex [4-Hf(Me) $\left.\left(\mathrm{NMe}\left(\mathrm{C}_{18} \mathrm{H}_{37}\right)_{2}\right)\right]^{+}\left[\mathrm{B}\left(\mathrm{C}_{6} \mathrm{~F}_{5}\right)_{4}\right]^{-}$was also generated in the reaction of 4- $\mathrm{HfMe}_{2}$ and $\left[\mathrm{Me}\left(\mathrm{C}_{18} \mathrm{H}_{37}\right)_{2} \mathrm{~N}-\mathrm{H}\right]^{+}\left[\mathrm{B}\left(\mathrm{C}_{6} \mathrm{~F}_{5}\right)_{4}\right]^{-}$(Supplementary Materials Figure S12). However, in this case, some insoluble fractions were concomitantly generated. We suspected that the insoluble fraction was a dinuclear adduct of $[4-\mathrm{Hf}(\mathrm{Me})]^{+}\left[\mathrm{B}\left(\mathrm{C}_{6} \mathrm{~F}_{5}\right)_{4}\right]^{-}$and $4-\mathrm{HfMe}_{2}$ (i.e., [4$\mathrm{Hf}(\mathrm{Me})(\mu-\mathrm{Me})(4-\mathrm{Hf}(\mathrm{Me}))]^{+}\left[\mathrm{B}\left(\mathrm{C}_{6} \mathrm{~F}_{5}\right)_{4}\right]^{-}$, which, however, disappeared after $1 \mathrm{~d}$, becoming soluble when 1.5 equiv $\left[\mathrm{Me}\left(\mathrm{C}_{18} \mathrm{H}_{37}\right)_{2} \mathrm{~N}-\mathrm{H}\right]^{+}\left[\mathrm{B}\left(\mathrm{C}_{6} \mathrm{~F}_{5}\right)_{4}\right]^{-}$was added to the activation reaction. In the ${ }^{1} \mathrm{H}$ NMR spectra, a signal at $\sim 5.1 \mathrm{ppm}$ which corresponded to $\mathrm{N}-\mathrm{H}$ in the remaining $\left[\mathrm{Me}\left(\mathrm{C}_{18} \mathrm{H}_{37}\right)_{2} \mathrm{~N}-\mathrm{H}\right]^{+}\left[\mathrm{B}\left(\mathrm{C}_{6} \mathrm{~F}_{5}\right)_{4}\right]^{-}$was persistently observed, indicating further reaction of the activated species [3- and 4- $\left.\mathrm{Hf}(\mathrm{Me})\left(\mathrm{NMe}\left(\mathrm{C}_{18} \mathrm{H}_{37}\right)_{2}\right)\right]^{+}\left[\mathrm{B}\left(\mathrm{C}_{6} \mathrm{~F}_{5}\right)_{4}\right]^{-}$with $\left[\mathrm{Me}\left(\mathrm{C}_{18} \mathrm{H}_{37}\right)_{2} \mathrm{~N}\right.$ $\mathrm{H}]^{+}\left[\mathrm{B}\left(\mathrm{C}_{6} \mathrm{~F}_{5}\right)_{4}\right]^{-}$was not allowed (Figure 5 and Supplementary Materials Figure S12). The N-H proton in $\left[\mathrm{Me}\left(\mathrm{C}_{18} \mathrm{H}_{37}\right)_{2} \mathrm{~N}-\mathrm{H}\right]^{+}\left[\mathrm{B}\left(\mathrm{C}_{6} \mathrm{~F}_{5}\right)_{4}\right]^{-}$was observed as a broad signal at $\sim 3.2 \mathrm{ppm}$ in $\mathrm{C}_{6} \mathrm{D}_{6}$ (Figure 1e) which, however, was shifted to $\sim 5.1 \mathrm{ppm}$ when recorded in $\mathrm{C}_{6} \mathrm{D}_{12}$ (Supplementary Materials Figure S11). 


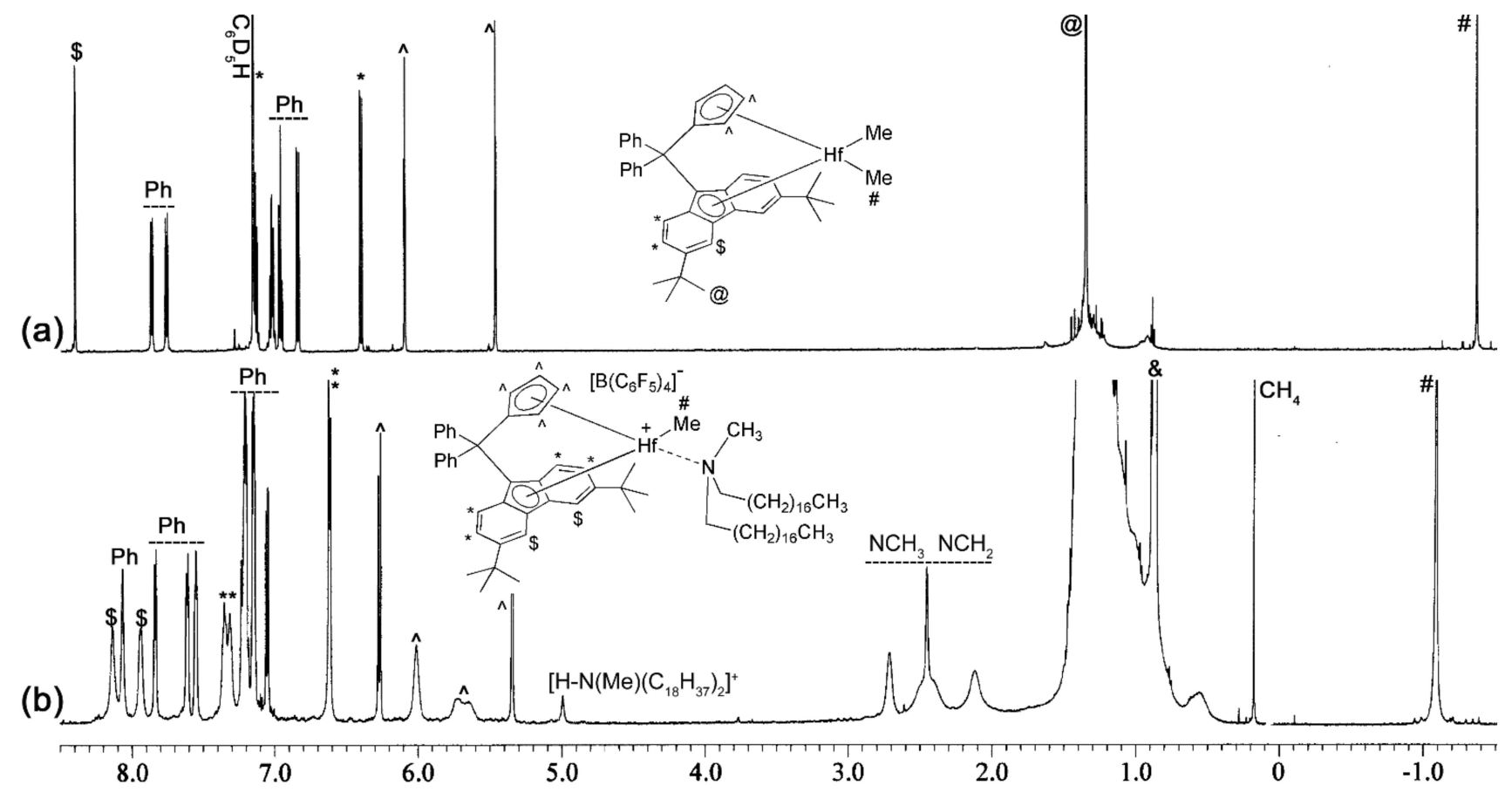

Figure 5. ${ }^{1} \mathrm{H}$ NMR spectra of 3-HfMe 2 (a) and its activated complex $\left[3-\mathrm{Hf}(\mathrm{Me})\left(\mathrm{NMe}\left(\mathrm{C}_{18} \mathrm{H}_{37}\right)_{2}\right)\right]^{+}\left[\mathrm{B}\left(\mathrm{C}_{6} \mathrm{~F}_{5}\right)_{4}\right]^{-}(\mathbf{b})$. Signals marked with $\$, *, \hat{*} @, \&$, and \# characters correspond to protons marked with those characters in the structure.

The activation reaction of half-metallocene titanium complexes is complicated. When 5$\mathrm{TiMe}_{2}$ was reacted with an equivalent $\left[\mathrm{Me}\left(\mathrm{C}_{18} \mathrm{H}_{37}\right)_{2} \mathrm{~N}-\mathrm{H}\right]^{+}\left[\mathrm{B}\left(\mathrm{C}_{6} \mathrm{~F}_{5}\right)_{4}\right]^{-}$in $\mathrm{C}_{6} \mathrm{D}_{12}$, the reactant signals in the ${ }^{1} \mathrm{H}$ NMR spectrum immediately disappeared with the generation of the $\mathrm{CH}_{4}$ signal, but the signals were too complicated to be interpreted. However, they converged to a set of assignable signals overnight (Supplementary Materials Figure S13). The generated species was not the desired ion-pair complex [5-Ti(Me) $\left.\left(\mathrm{NMe}\left(\mathrm{C}_{18} \mathrm{H}_{37}\right)_{2}\right)\right]^{+}\left[\mathrm{B}\left(\mathrm{C}_{6} \mathrm{~F}_{5}\right)_{4}\right]^{-}$; the Ti- $\mathrm{CH}_{3}$ signal was not observed, but, instead, two broad signals were observed at 0.45 and $-0.71 \mathrm{ppm}$, whose intensity was $1 / 3$ relative to that of the $\mathrm{C}_{5} \mathrm{CH}_{3}$ or $\mathrm{SiCH}_{3}$ signal. We tentatively assigned the generated species to $\left[5-\mathrm{Ti}\left(\mathrm{CH}_{2} \mathrm{~N}\left(\mathrm{C}_{18} \mathrm{H}_{37}\right)_{2}\right)\right]^{+}\left[\mathrm{B}\left(\mathrm{C}_{6} \mathrm{~F}_{5}\right)_{4}\right]^{-}$, which may have been formed from [5-Ti(Me) $\left.\left(\mathrm{NMe}\left(\mathrm{C}_{18} \mathrm{H}_{37}\right)_{2}\right)\right]^{+}\left[\mathrm{B}\left(\mathrm{C}_{6} \mathrm{~F}_{5}\right)_{4}\right]^{-}$via an intramolecular $\sigma$-bond metathesis reaction with the generation of $\mathrm{CH}_{4}$ (Scheme 5). With the species [5- $\left.\mathrm{Ti}\left(\mathrm{CH}_{2} \mathrm{~N}\left(\mathrm{C}_{18} \mathrm{H}_{37}\right)_{2}\right)\right]^{+}\left[\mathrm{B}\left(\mathrm{C}_{6} \mathrm{~F}_{5}\right)_{4}\right]^{-}$, the four $\mathrm{NCH}_{2}$ protons, the four methyl groups attached to cyclopentadienyl ligand, and the two methyl groups attached to $\mathrm{Si}$ are separately observed at 3.29, 2.93, 2.77, 2.51, 2.20, 2.08, 1.88, $1.83,0.75$, and $0.58 \mathrm{ppm}$ with intensity ratios of roughly 1:1:1:1:3:3:3:3:3:3, respectively, along with Ti- $\mathrm{CH}_{2}$ signals at 0.45 and $-0.71 \mathrm{ppm}$ with intensity ratios of roughly 1 and 1 , respectively. The same type of complex, $\left[\mathrm{Cp}_{2} \mathrm{Zr}\left(\mathrm{CH}_{2} \mathrm{~N}\left(\mathrm{C}_{18} \mathrm{H}_{37}\right)_{2}\right)\right]^{+}\left[\mathrm{B}\left(\mathrm{C}_{6} \mathrm{~F}_{5}\right)_{4}\right]^{-}$, was reported for the activation reaction of $\mathrm{Cp}_{2} \mathrm{ZrMe}_{2}[46-48]$, and a similar transformation of $[\mathrm{L}-\mathrm{M}(\mathrm{Me})]^{+}\left[\mathrm{B}\left(\mathrm{C}_{6} \mathrm{~F}_{5}\right)_{4}\right]^{-}$type complexes to other species (via the $\sigma$-bond metathesis reaction with formation of other $\mathrm{M}-\mathrm{C}$ bonds and generation of $\mathrm{CH}_{4}$ ) has also been reported for other metallocene and postmetallocene complexes [31,49-51]. Action of $\left[\mathrm{Me}\left(\mathrm{C}_{18} \mathrm{H}_{37}\right)_{2} \mathrm{~N}-\mathrm{H}\right]^{+}\left[\mathrm{B}\left(\mathrm{C}_{6} \mathrm{~F}_{5}\right)_{4}\right]^{-}$to Hf-based metallocene (e.g., 3- and 4-HfMe ${ }_{2}$ ), half-metallocene (e.g., 6- $\mathrm{HfMe}_{2}$ ), and post-metallocene (e.g., pyridylamido-HfMe 2 ) complexes usually afforded stable $\left[\mathrm{L}-\mathrm{Hf}(\mathrm{Me})\left(\mathrm{NMe}\left(\mathrm{C}_{18} \mathrm{H}_{37}\right)_{2}\right)\right]^{+}$ $\left[\mathrm{B}\left(\mathrm{C}_{6} \mathrm{~F}_{5}\right)_{4}\right]^{-}$type ion pair complexes [37]. In contrast, stability of $\left[\mathrm{L}-\mathrm{Zr}(\mathrm{Me})\left(\mathrm{NMe}\left(\mathrm{C}_{18} \mathrm{H}_{37}\right)_{2}\right)\right]^{+}$ $\left[\mathrm{B}\left(\mathrm{C}_{6} \mathrm{~F}_{5}\right)_{4}\right]^{-}$type ion pair complexes generated from $\mathrm{Zr}$-based metallocenes (e.g., 1-ZrMe ${ }_{2}$, $2-\mathrm{ZrMe}_{2}, \mathrm{Cp}_{2} \mathrm{ZrMe}_{2}$ ) depended on the ligand structure while those species generated from Ti-based half-metallocene complexes were unstable in all cases (see also below). These stability difference might be attributed to $\mathrm{M}-\mathrm{C}$ bond strength, which increases by moving from Ti to $\mathrm{Zr}$ and further to Hf. 


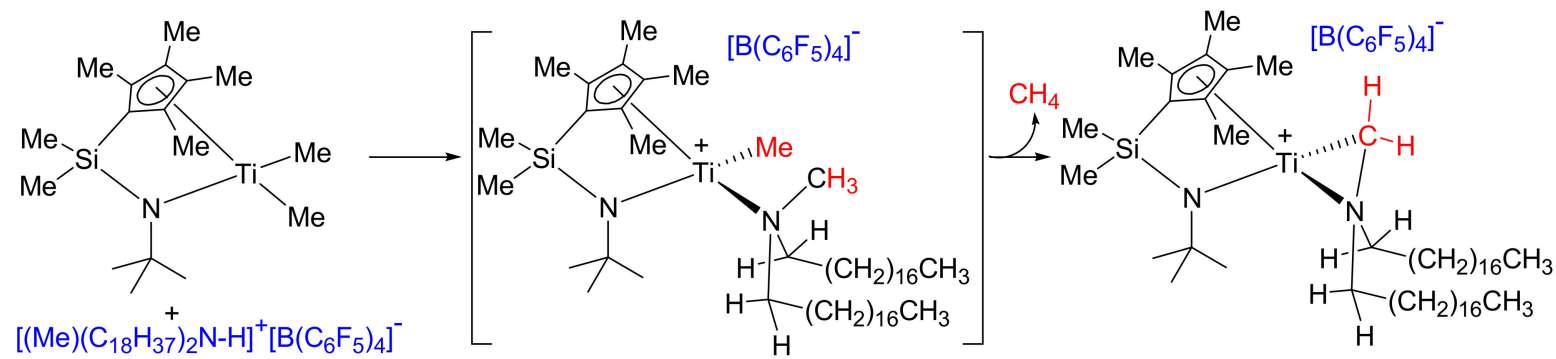

Scheme 5. Activation reaction of a half-metallocene complex.

The addition of 1.5 equiv $\left[\mathrm{Me}\left(\mathrm{C}_{18} \mathrm{H}_{37}\right)_{2} \mathrm{~N}-\mathrm{H}\right]^{+}\left[\mathrm{B}\left(\mathrm{C}_{6} \mathrm{~F}_{5}\right)_{4}\right]^{-}$to 6-TiMe 2 afforded a clean set of signals at an initial stage $(<15 \mathrm{~min})$ that were assigned to the desired activated complex [6- $\left.\mathrm{Ti}(\mathrm{Me})\left(\mathrm{NMe}\left(\mathrm{C}_{18} \mathrm{H}_{37}\right)_{2}\right)\right]^{+}\left[\mathrm{B}\left(\mathrm{C}_{6} \mathrm{~F}_{5}\right)_{4}\right]^{-}$(Figure 6b) [37]. The tetrahydroquinoline$\mathrm{NCH}_{2}$ protons were separately observed at 5.04 and $4.01 \mathrm{ppm}$ and four methyl groups attached to cyclopentadienyl ligand were observed independently at 2.31,2.04, 1.82, and $1.70 \mathrm{ppm}$. The signal corresponding to $\mathrm{Ti}-\mathrm{CH}_{3}$ was observed at $0.91 \mathrm{ppm}$. However, overnight, the signals corresponding to $\left[6-\mathrm{Ti}(\mathrm{Me})\left(\mathrm{NMe}\left(\mathrm{C}_{18} \mathrm{H}_{37}\right)_{2}\right)\right]^{+}\left[\mathrm{B}\left(\mathrm{C}_{6} \mathrm{~F}_{5}\right)_{4}\right]^{-}$disappeared completely and were converted to a new set of signals that were too broad to be interpreted(Figure 6c). We hypothesized that $\left[6-\mathrm{Ti}(\mathrm{Me})\left(\mathrm{NMe}\left(\mathrm{C}_{18} \mathrm{H}_{37}\right)_{2}\right)\right]^{+}\left[\mathrm{B}\left(\mathrm{C}_{6} \mathrm{~F}_{5}\right)_{4}\right]^{-}$ was converted to $\left[6-\mathrm{Ti}\left(\mathrm{CH}_{2} \mathrm{~N}\left(\mathrm{C}_{18} \mathrm{H}_{37}\right)_{2}\right)\right]^{+}\left[\mathrm{B}\left(\mathrm{C}_{6} \mathrm{~F}_{5}\right)_{4}\right]^{-}$overnight as in the activation reaction of $5-\mathrm{TiMe}_{2}$. An activation reaction with 1 equiv $\left[\mathrm{Me}\left(\mathrm{C}_{18} \mathrm{H}_{37}\right)_{2} \mathrm{~N}-\mathrm{H}\right]^{+}\left[\mathrm{B}\left(\mathrm{C}_{6} \mathrm{~F}_{5}\right)_{4}\right]^{-}$ instead of 1.5 equiv afforded similar results, with no generation of an insoluble fraction, but several other tetrahydroquinoline- $\mathrm{NCH}_{2}$ signals were observed in the 3.54-4.76 ppm region, along with the main ones assigned to $\left[6-\mathrm{Ti}(\mathrm{Me})\left(\mathrm{NMe}\left(\mathrm{C}_{18} \mathrm{H}_{37}\right)_{2}\right)\right]^{+}\left[\mathrm{B}\left(\mathrm{C}_{6} \mathrm{~F}_{5}\right)_{4}\right]^{-}$. The reaction of 6 - $\mathrm{TiMe}_{2}$ with the bulkier $\left[\left(\mathrm{C}_{12} \mathrm{H}_{25}\right)_{3} \mathrm{~N}-\mathrm{H}\right]^{+}\left[\mathrm{B}\left(\mathrm{C}_{6} \mathrm{~F}_{5}\right)_{4}\right]^{-}$was not clean; many insoluble species were deposited in $\mathrm{C}_{6} \mathrm{D}_{12}$ and the ${ }^{1} \mathrm{H}$ NMR spectrum signals were too complicated to be interpreted. In the reaction pot of $6-\mathrm{TiMe}_{2}$ with secondary amine-derived salt $\left[\left(\mathrm{C}_{18} \mathrm{H}_{37}\right)_{2} \mathrm{NH}_{2}\right]^{+}\left[\mathrm{B}\left(\mathrm{C}_{6} \mathrm{~F}_{5}\right)_{4}\right]^{-}$in $\mathrm{C}_{6} \mathrm{D}_{12}$, two species were observed at the initial stage with no generation of insoluble fractions, which were assigned to [6$\left.\mathrm{Ti}(\mathrm{Me})\left(\mathrm{N}(\mathrm{H})\left(\mathrm{C}_{18} \mathrm{H}_{37}\right)_{2}\right)\right]^{+}\left[\mathrm{B}\left(\mathrm{C}_{6} \mathrm{~F}_{5}\right)_{4}\right]^{-}$and $\left[6-\mathrm{Ti}\left(\mathrm{N}\left(\mathrm{C}_{18} \mathrm{H}_{37}\right)_{2}\right)\right]^{+}\left[\mathrm{B}\left(\mathrm{C}_{6} \mathrm{~F}_{5}\right)_{4}\right]^{-}$(Supplementary Materials Figure S14). However, after $2 \mathrm{~h}$, the signals assigned to the former completely disappeared, cleanly leaving a set of signals assigned to the latter. The reaction pattern between 7-TiMe 2 and $\left[\mathrm{Me}\left(\mathrm{C}_{18} \mathrm{H}_{37}\right)_{2} \mathrm{~N}-\mathrm{H}\right]^{+}\left[\mathrm{B}\left(\mathrm{C}_{6} \mathrm{~F}_{5}\right)_{4}\right]^{-}$was similar to that of 6- $\mathrm{TiMe}_{2}$ (Supplementary Materials Figure S15).

For L-TiMe ${ }_{2}$-type half-metallocene complexes, the desired activated complexes, [L$\left.\mathrm{Ti}(\mathrm{Me})\left(\mathrm{NMe}\left(\mathrm{C}_{18} \mathrm{H}_{37}\right)_{2}\right)\right]^{+}\left[\mathrm{B}\left(\mathrm{C}_{6} \mathrm{~F}_{5}\right)_{4}\right]^{-}$, were unstable and slowly transformed to other species that we tentatively assigned to $\left[\mathrm{L}-\mathrm{Ti}\left(\mathrm{CH}_{2} \mathrm{~N}\left(\mathrm{C}_{18} \mathrm{H}_{37}\right)_{2}\right)\right]^{+}\left[\mathrm{B}\left(\mathrm{C}_{6} \mathrm{~F}_{5}\right)_{4}\right]^{-}$. To prevent further reactions with $\left[\mathrm{L}-\mathrm{Ti}(\mathrm{Me})\left(\mathrm{NMe}\left(\mathrm{C}_{18} \mathrm{H}_{37}\right)_{2}\right)\right]^{+}\left[\mathrm{B}\left(\mathrm{C}_{6} \mathrm{~F}_{5}\right)_{4}\right]^{-}$, $\mathrm{L}-\mathrm{MCl}(\mathrm{Me})$-type complexes were prepared and reacted with $\left[\mathrm{Me}\left(\mathrm{C}_{18} \mathrm{H}_{37}\right)_{2} \mathrm{~N}-\mathrm{H}\right]^{+}\left[\mathrm{B}\left(\mathrm{C}_{6} \mathrm{~F}_{5}\right)_{4}\right]^{-}$. The reaction of $6-\mathrm{TiCl}(\mathrm{Me})$ with $\left[\mathrm{Me}\left(\mathrm{C}_{18} \mathrm{H}_{37}\right)_{2} \mathrm{~N}-\mathrm{H}\right]^{+}\left[\mathrm{B}\left(\mathrm{C}_{6} \mathrm{~F}_{5}\right)_{4}\right]^{-}$in $\mathrm{C}_{6} \mathrm{D}_{12}$ did not afford a single species, many insoluble fractions were generated, and the ${ }^{1} \mathrm{H}$ NMR signals were too broad and too complicated to be interpreted. In contrast, the reaction of 6- $\mathrm{TiCl}(\mathrm{Me})$ with secondary aminederived $\left[\left(\mathrm{C}_{18} \mathrm{H}_{37}\right)_{2} \mathrm{NH}_{2}\right]^{+}\left[\mathrm{B}\left(\mathrm{C}_{6} \mathrm{~F}_{5}\right)_{4}\right]^{-}$(1.1 equiv) afforded a clean set of signals, which could be assigned to the desired complex $\left[6-\mathrm{TiCl}\left(\mathrm{N}(\mathrm{H})\left(\mathrm{C}_{18} \mathrm{H}_{37}\right)_{2}\right)\right]^{+}\left[\mathrm{B}\left(\mathrm{C}_{6} \mathrm{~F}_{5}\right)_{4}\right]^{-}$, with no generation of insoluble fractions (Supplementary Materials Figure S5); the signal pattern was similar to that observed for $\left[6-\mathrm{Ti}(\mathrm{Me})\left(\mathrm{NMe}\left(\mathrm{C}_{18} \mathrm{H}_{37}\right)_{2}\right)\right]^{+}\left[\mathrm{B}\left(\mathrm{C}_{6} \mathrm{~F}_{5}\right)_{4}\right]^{-}$(Figure 6b) with tetrahydroquinoline- $\mathrm{NCH}_{2}$ signals observed at 5.04 and $4.01 \mathrm{ppm}$ and the $\mathrm{TiCH}_{3}$ signal absent. Signals assigned to 6- $\mathrm{TiCl}_{2}$ were also observed at approximately $10 \mathrm{~mol} \%$. The addition of 1.1 equiv $\left[\left(\mathrm{C}_{18} \mathrm{H}_{37}\right)_{2} \mathrm{NH}_{2}\right]^{+}\left[\mathrm{B}\left(\mathrm{C}_{6} \mathrm{~F}_{5}\right)_{4}\right]^{-}$to $5-\mathrm{TiCl}(\mathrm{Me})$ also resulted in the generation of the desired complex $\left[5-\mathrm{TiCl}\left(\mathrm{N}(\mathrm{H})\left(\mathrm{C}_{18} \mathrm{H}_{37}\right)_{2}\right)\right]^{+}\left[\mathrm{B}\left(\mathrm{C}_{6} \mathrm{~F}_{5}\right)_{4}\right]^{-}$(Figure 7); a signal corresponding to Ti- $\mathrm{CH}_{3}$ in the reactant disappeared completely and the $\mathrm{CH}_{4}$ signal appeared along with a shift of $\mathrm{C}_{5} \mathrm{CH}_{3}$ signals. $\mathrm{NH}$ and $\mathrm{NCH}_{2}$ signals were observed at 
2.75-2.51. A set of signals that could be assigned to $5-\mathrm{TiCl}_{2}$ was also observed at an amount of approximately $10 \mathrm{~mol} \%$, as was observed in the activation reaction of $6-\mathrm{TiCl}(\mathrm{Me})$.
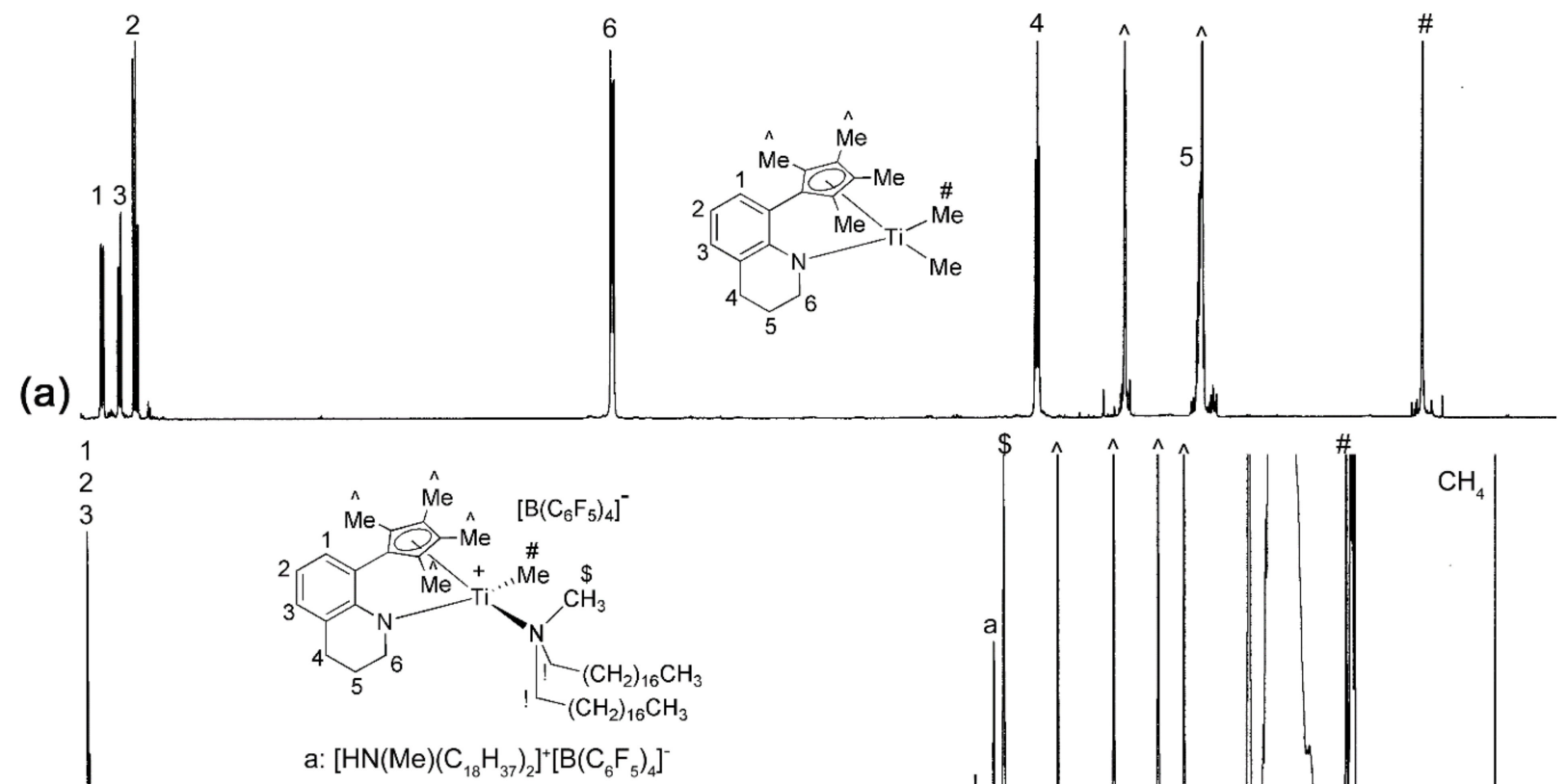

(b) he

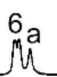

(c)

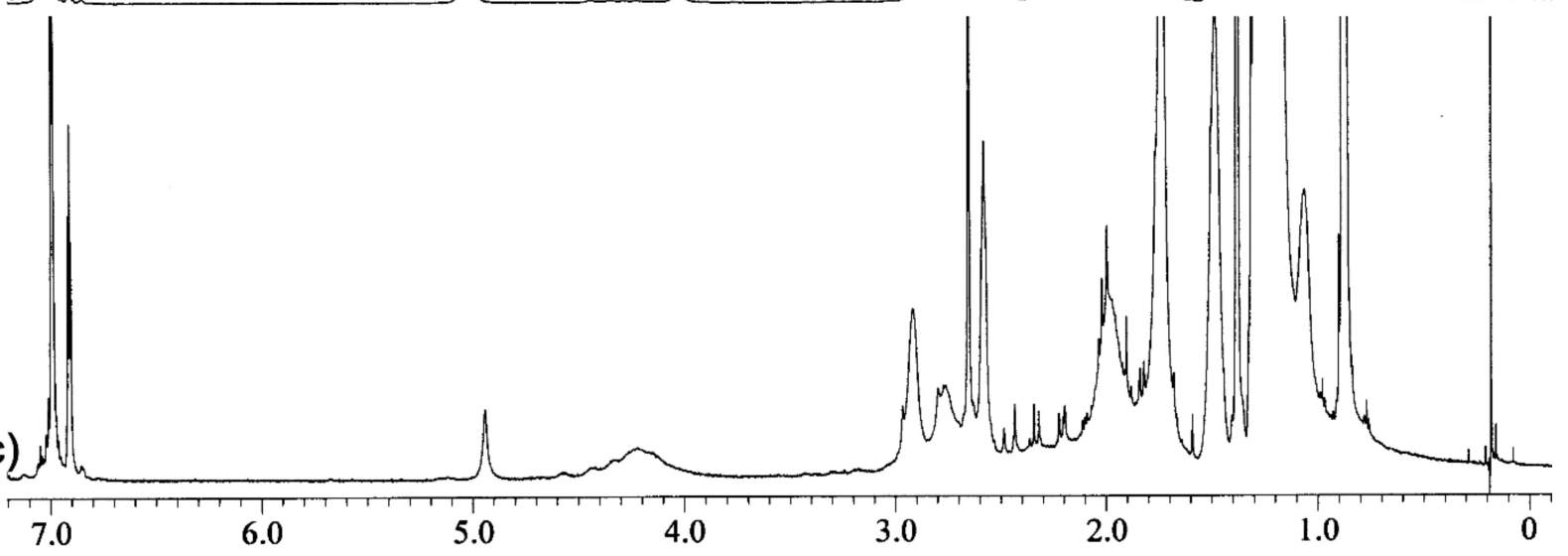

Figure 6. ${ }^{1} \mathrm{H}$ NMR spectra of 6-TiMe 2 (a) and its activated complex $\left[6-\mathrm{Ti}\left(\mathrm{CH}_{2} \mathrm{~N}\left(\mathrm{C}_{18} \mathrm{H}_{37}\right)_{2}\right)\right]^{+}\left[\mathrm{B}\left(\mathrm{C}_{6} \mathrm{~F}_{5}\right)_{4}\right]^{-}$formed at an initial stage (b) and transformed to another species overnight (c). Signals marked with !, \$,, , and \# characters correspond to protons marked with those characters in the structure. 
(a)

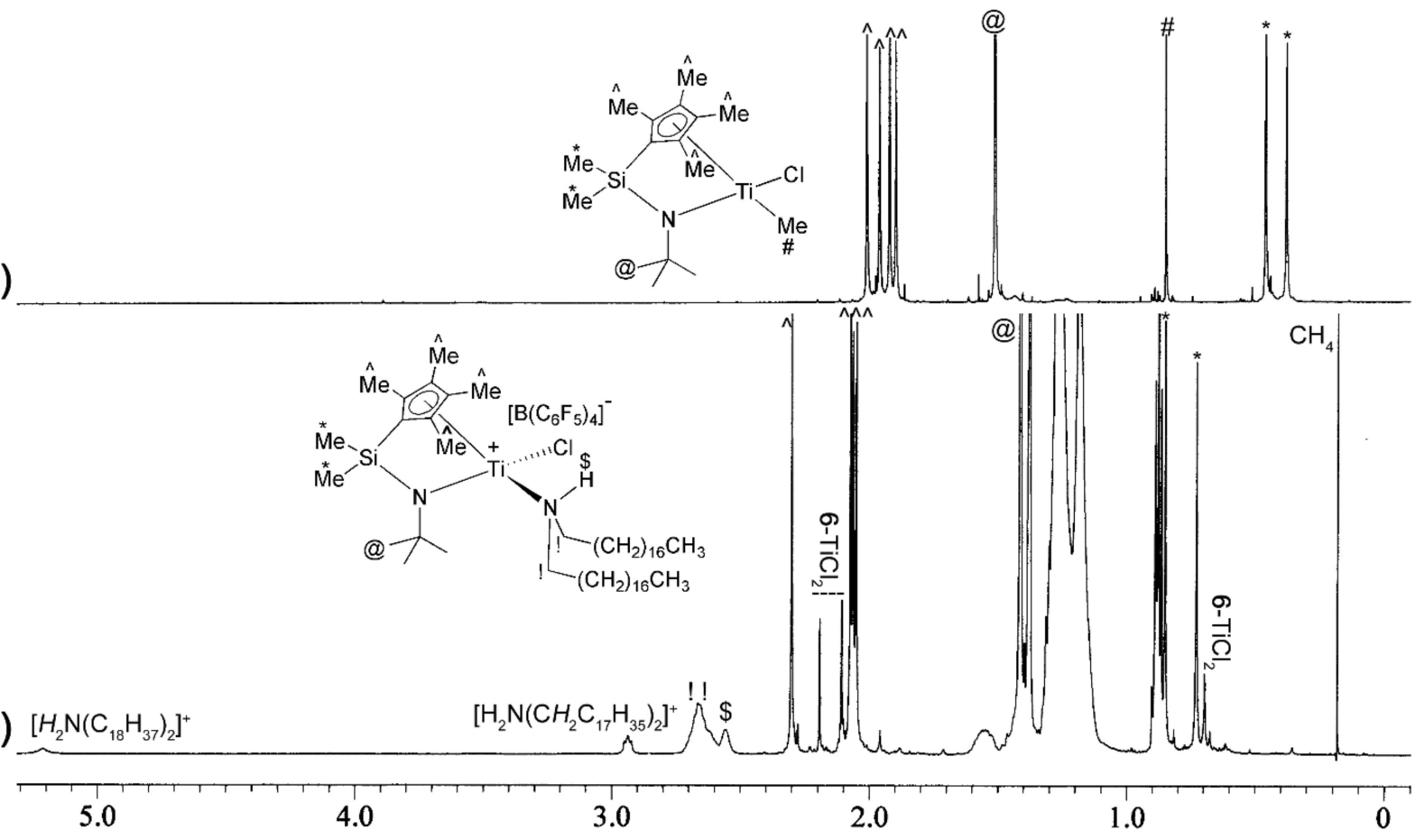

Figure 7. ${ }^{1} \mathrm{H}$ NMR spectra of $5-\mathrm{TiCl}(\mathrm{Me})(\mathbf{a})$ and its activated complex $\left[5-\mathrm{TiCl}\left(\mathrm{N}(\mathrm{H})\left(\mathrm{C}_{18} \mathrm{H}_{37}\right)_{2}\right)\right]^{+}\left[\mathrm{B}\left(\mathrm{C}_{6} \mathrm{~F}_{5}\right)_{4}\right]^{-}(\mathbf{b})$. Signals marked with !, \$,,$@$, \#, and * characters correspond to protons marked with those characters in the structure.

\subsection{Polymerization Studies}

The performance of the activated species was tested in an olefin polymerization performed in a small-sized $(75 \mathrm{~mL})$ bomb reactor under 20 bar of ethylene gas by using hexane solvent $(15.5 \mathrm{~g})$ and 1-octene comonomer $(5.0 \mathrm{~g})$ with a small amount of trioctylaluminum as a scavenger $\left(\mathrm{Al} / \mathrm{L}-\mathrm{M}(\mathrm{Me})_{2}=33\right)$. The temperature could not be controlled; it increased from $65{ }^{\circ} \mathrm{C}$ up to $164{ }^{\circ} \mathrm{C}$ within several minutes due to the heat generated by the exothermic reaction (Table 1). Instead, temperature was recorded in an isothermal $110^{\circ} \mathrm{C}$ bath, which enabled us to qualitatively monitor the performance of the catalyst. When $\left[1-\mathrm{Zr}(\mathrm{Me})\left(\mathrm{NMe}\left(\mathrm{C}_{18} \mathrm{H}_{37}\right)_{2}\right)\right]^{+}\left[\mathrm{B}\left(\mathrm{C}_{6} \mathrm{~F}_{5}\right)_{4}\right]^{-}(1.0 \mu \mathrm{mol})$ was fed into the reactor at a temperature of $65^{\circ} \mathrm{C}$, the temperature increased immediately, reaching $116^{\circ} \mathrm{C}$ in $2 \mathrm{~min}$, and then gradually decreased, reaching $94^{\circ} \mathrm{C}$ after $15 \mathrm{~min}$, when the polymerization was quenched. A large amount of polymer was formed as a form of slurry ( $9.3 \mathrm{~g}$; entry 1), which indicated that 1-octene incorporation was not significant. In contrast, when [3- $\left.\mathrm{Hf}(\mathrm{Me})\left(\mathrm{NMe}\left(\mathrm{C}_{18} \mathrm{H}_{37}\right)_{2}\right)\right]^{+}\left[\mathrm{B}\left(\mathrm{C}_{6} \mathrm{~F}_{5}\right)_{4}\right]^{-}$was fed, the temperature slowly increased for 10 min until reaching $82{ }^{\circ} \mathrm{C}$, after which, the temperature increased dramatically, reaching $164{ }^{\circ} \mathrm{C}$ in $2 \mathrm{~min}$, after which the temperature gradually decreased to $91{ }^{\circ} \mathrm{C}$ during the rest 13 min polymerization time (entry 2). Amine $\mathrm{NMe}\left(\mathrm{C}_{18} \mathrm{H}_{37}\right)_{2}$ should be detached from the Hf center to initiate polymerization, which might require a temperature of at least $80^{\circ} \mathrm{C}$. Even with the much higher temperature rise $\left(164\right.$ vs. $\left.116^{\circ} \mathrm{C}\right)$ relative to [1$\left.\mathrm{Zr}(\mathrm{Me})\left(\mathrm{NMe}\left(\mathrm{C}_{18} \mathrm{H}_{37}\right)_{2}\right)\right]^{+}\left[\mathrm{B}\left(\mathrm{C}_{6} \mathrm{~F}_{5}\right)_{4}\right]^{-}$, the amount of generated polymer was less $(5.2 \mathrm{~g}$ vs. $9.3 \mathrm{~g})$. In the case of $\left[3-\mathrm{Hf}(\mathrm{Me})\left(\mathrm{NMe}\left(\mathrm{C}_{18} \mathrm{H}_{37}\right)_{2}\right)\right]^{+}\left[\mathrm{B}\left(\mathrm{C}_{6} \mathrm{~F}_{5}\right)_{4}\right]^{-}$, the generated polymer was not a slurry but a form dissolved in hexane, indicating that 1-octene incorporation was significant. In fact, the 1-octene content $\left(F_{\mathrm{C} 8}\right)$ in the generated copolymer was significantly higher than that in the copolymer generated with $\left[1-\mathrm{Ti}(\mathrm{Me})\left(\mathrm{NMe}\left(\mathrm{C}_{18} \mathrm{H}_{37}\right)_{2}\right)\right]^{+}\left[\mathrm{B}\left(\mathrm{C}_{6} \mathrm{~F}_{5}\right)_{4}\right]^{-}$ (33 vs. $18 \mathrm{~mol} \%)$. Another hafnium species $\left[4-\mathrm{Hf}(\mathrm{Me})\left(\mathrm{NMe}\left(\mathrm{C}_{18} \mathrm{H}_{37}\right)_{2}\right)\right]^{+}\left[\mathrm{B}\left(\mathrm{C}_{6} \mathrm{~F}_{5}\right)_{4}\right]^{-}$ showed a slightly lower yield than $\left[3-\mathrm{Hf}(\mathrm{Me})\left(\mathrm{NMe}\left(\mathrm{C}_{18} \mathrm{H}_{37}\right)_{2}\right)\right]^{+}\left[\mathrm{B}\left(\mathrm{C}_{6} \mathrm{~F}_{5}\right)_{4}\right]^{-}$(yield 5.0 vs. $5.2 \mathrm{~g}$; entry 3 vs. 2), but the yield was increased to $5.4 \mathrm{~g}$, using 1.5 equiv (instead of 1.0 equiv) $\left[\mathrm{Me}\left(\mathrm{C}_{18} \mathrm{H}_{37}\right)_{2} \mathrm{~N}-\mathrm{H}\right]^{+}\left[\mathrm{B}\left(\mathrm{C}_{6} \mathrm{~F}_{5}\right)_{4}\right]^{-}$in the activation reaction, upon which the insoluble side-product was completely dissolved. The 1-octene incorporation capability of $\left[4-\mathrm{Hf}(\mathrm{Me})\left(\mathrm{NMe}\left(\mathrm{C}_{18} \mathrm{H}_{37}\right)_{2}\right)\right]^{+}\left[\mathrm{B}\left(\mathrm{C}_{6} \mathrm{~F}_{5}\right)_{4}\right]^{-}$was slightly better than that of [3- 
$\left.\mathrm{Hf}(\mathrm{Me})\left(\mathrm{NMe}\left(\mathrm{C}_{18} \mathrm{H}_{37}\right)_{2}\right)\right]^{+}\left[\mathrm{B}\left(\mathrm{C}_{6} \mathrm{~F}_{5}\right)_{4}\right]^{-}\left(F_{\mathrm{C} 8}, 34-35\right.$ vs. $\left.33 \mathrm{~mol} \%\right)$, and the $F_{\mathrm{C} 8}$ values (33$35 \mathrm{~mol} \%$ ) measured for the copolymers generated with the hafnium species were comparable to or even higher than those measured for those generated with half-metallocene titanium species (24-35 mol\%), which are known to be excellent for the incorporation of $\alpha$-olefin. All the half-metallocene Ti species tested afforded polymers in a form dissolved in hexane.

Table 1. Polymerization results ${ }^{a}$.

\begin{tabular}{|c|c|c|c|c|c|c|}
\hline Entry & Catalyst & $\begin{array}{c}\text { Temperature } \\
\left({ }^{\circ} \mathrm{C}\right)\end{array}$ & $\begin{array}{c}\text { Yield } \\
\text { (g) }\end{array}$ & $\begin{array}{c}F_{\text {Oct }}{ }^{c} \\
(\mathrm{~mol} \%)\end{array}$ & $\begin{array}{l}M_{\mathrm{w}} \mathrm{d} \\
(\mathrm{kDa})\end{array}$ & $M_{\mathrm{w}} / M_{\mathrm{n}}$ \\
\hline 1 & {$\left[1-\mathrm{Zr}(\mathrm{Me})\left(\mathrm{NMe}\left(\mathrm{C}_{18} \mathrm{H}_{37}\right)_{2}\right)\right]^{+}\left[\mathrm{B}\left(\mathrm{C}_{6} \mathrm{~F}_{5}\right)_{4}\right]^{-}$} & $65-116-94$ & 9.3 & 18 & 32 & 13 \\
\hline 2 & {$\left[3-\mathrm{Hf}(\mathrm{Me})\left(\mathrm{NMe}\left(\mathrm{C}_{18} \mathrm{H}_{37}\right)_{2}\right)\right]^{+}\left[\mathrm{B}\left(\mathrm{C}_{6} \mathrm{~F}_{5}\right)_{4}\right]^{-}$} & $82-164-91$ & 5.2 & 33 & 716 & 39 \\
\hline 3 & {$\left[4-\mathrm{Hf}(\mathrm{Me})\left(\mathrm{NMe}\left(\mathrm{C}_{18} \mathrm{H}_{37}\right)_{2}\right)\right]^{+}\left[\mathrm{B}\left(\mathrm{C}_{6} \mathrm{~F}_{5}\right)_{4}\right]^{-}$} & 78-161-91 & 5.0 & 34 & 814 & 56 \\
\hline $4^{\mathrm{e}}$ & {$\left[4-\mathrm{Hf}(\mathrm{Me})\left(\mathrm{NMe}\left(\mathrm{C}_{18} \mathrm{H}_{37}\right)_{2}\right)\right]^{+}\left[\mathrm{B}\left(\mathrm{C}_{6} \mathrm{~F}_{5}\right)_{4}\right]^{-}$} & 65-159-95 & 5.4 & 35 & 696 & 78 \\
\hline 5 & {$\left[5-\mathrm{Ti}\left(\mathrm{CH}_{2} \mathrm{~N}\left(\mathrm{C}_{18} \mathrm{H}_{37}\right)_{2}\right)\right]^{+}\left[\mathrm{B}\left(\mathrm{C}_{6} \mathrm{~F}_{5}\right)_{4}\right]^{-}$} & $65-141-82$ & 4.9 & 35 & 150 & 13 \\
\hline $6^{\mathrm{e}}$ & {$\left[5-\mathrm{Ti}\left(\mathrm{CH}_{2} \mathrm{~N}\left(\mathrm{C}_{18} \mathrm{H}_{37}\right)_{2}\right)\right]^{+}\left[\mathrm{B}\left(\mathrm{C}_{6} \mathrm{~F}_{5}\right)_{4}\right]^{-}$} & $65-126-83$ & 6.2 & 29 & 103 & 7.3 \\
\hline $7^{\mathrm{f}}$ & {$\left[5-\mathrm{TiCl}\left(\mathrm{N}(\mathrm{H})\left(\mathrm{C}_{18} \mathrm{H}_{37}\right)_{2}\right)\right]^{+}\left[\mathrm{B}\left(\mathrm{C}_{6} \mathrm{~F}_{5}\right)_{4}\right]^{-}$} & 89-115-99 & 4.5 & 25 & 211 & 3.6 \\
\hline 8 & {$\left[6-\mathrm{Ti}\left(\mathrm{CH}_{2} \mathrm{~N}\left(\mathrm{C}_{18} \mathrm{H}_{37}\right)_{2}\right)\right]^{+}\left[\mathrm{B}\left(\mathrm{C}_{6} \mathrm{~F}_{5}\right)_{4}\right]^{-}$} & $81-102-95$ & 4.4 & 27 & 269 & 2.3 \\
\hline $9^{\mathrm{e}}$ & {$\left[6-\mathrm{Ti}\left(\mathrm{CH}_{2} \mathrm{~N}\left(\mathrm{C}_{18} \mathrm{H}_{37}\right)_{2}\right)\right]^{+}\left[\mathrm{B}\left(\mathrm{C}_{6} \mathrm{~F}_{5}\right)_{4}\right]^{-}$} & $80-124-91$ & 5.3 & 29 & 237 & 2.5 \\
\hline $10 \mathrm{~g}$ & {$\left[6-\mathrm{Ti}\left(\mathrm{CH}_{2} \mathrm{~N}\left(\mathrm{C}_{18} \mathrm{H}_{37}\right)_{2}\right)\right]^{+}\left[\mathrm{B}\left(\mathrm{C}_{6} \mathrm{~F}_{5}\right)_{4}\right]^{-}$} & $71-129-83$ & 5.8 & 31 & 211 & 3.5 \\
\hline 11 & {$\left[6-\mathrm{Ti}\left(\mathrm{N}\left(\mathrm{C}_{18} \mathrm{H}_{37}\right)_{2}\right)\right]^{+}\left[\mathrm{B}\left(\mathrm{C}_{6} \mathrm{~F}_{5}\right)_{4}\right]^{-}$} & - & 0 & - & & \\
\hline $12^{\mathrm{f}}$ & {$\left[6-\mathrm{TiCl}\left(\mathrm{N}(\mathrm{H})\left(\mathrm{C}_{18} \mathrm{H}_{37}\right)_{2}\right)\right]^{+}\left[\mathrm{B}\left(\mathrm{C}_{6} \mathrm{~F}_{5}\right)_{4}\right]^{-}$} & $65-129-82$ & 4.2 & 32 & 213 & 2.7 \\
\hline $13^{\mathrm{h}}$ & {$\left[7-\mathrm{Ti}(\mathrm{Me})\left(\mathrm{NMe}\left(\mathrm{C}_{18} \mathrm{H}_{37}\right)_{2}\right)\right]^{+}\left[\mathrm{B}\left(\mathrm{C}_{6} \mathrm{~F}_{5}\right)_{4}\right]^{-}$} & $65-104-79$ & 5.6 & 35 & 209 & 2.9 \\
\hline 14 & {$\left[7-\mathrm{Ti}\left(\mathrm{CH}_{2} \mathrm{~N}\left(\mathrm{C}_{18} \mathrm{H}_{37}\right)_{2}\right)\right]^{+}\left[\mathrm{B}\left(\mathrm{C}_{6} \mathrm{~F}_{5}\right)_{4}\right]^{-}$} & 80-104-94 & 4.1 & 24 & 343 & 2.5 \\
\hline $15^{\mathrm{e}}$ & {$\left[7-\mathrm{Ti}\left(\mathrm{CH}_{2} \mathrm{~N}\left(\mathrm{C}_{18} \mathrm{H}_{37}\right)_{2}\right)\right]^{+}\left[\mathrm{B}\left(\mathrm{C}_{6} \mathrm{~F}_{5}\right)_{4}\right]^{-}$} & $65-119-85$ & 5.3 & 29 & 216 & 3.4 \\
\hline
\end{tabular}

${ }^{a}$ Polymerization conditions: L-MMe $2(1.0 \mu \mathrm{mol})$ activated with $\left[\mathrm{Me}\left(\mathrm{C}_{18} \mathrm{H}_{37}\right)_{2} \mathrm{~N}-\mathrm{H}\right]^{+}\left[\mathrm{B}\left(\mathrm{C}_{6} \mathrm{~F}_{5}\right)_{4}\right]^{-}(1.0$ or 1.5 equiv $)$ or L-MCl(Me) $(1.0 \mu \mathrm{mol})$ activated with $\left[\left(\mathrm{C}_{18} \mathrm{H}_{37}\right)_{2} \mathrm{NH}_{2}\right]^{+}\left[\mathrm{B}\left(\mathrm{C}_{6} \mathrm{~F}_{5}\right)_{4}\right]^{-}(1.1$ equiv), trioctylaluminum $(33 \mu \mathrm{mol})$ as a scavenger, hexane (15.5 g), 1-octene (5.0 g), ethylene (20 bar), 15 min. ${ }^{b}$ Temperature was not controlled (temperature starting to rise/the highest temperature reached after several minutes/temperature at the end of polymerization). ${ }^{\mathrm{c}}$ 1-Octene content measured by ${ }^{1} \mathrm{H}-\mathrm{NMR}$ spectra. ${ }^{\mathrm{d}}$ Measured by GPC at $160{ }^{\circ} \mathrm{C}$, using trichlorobenzene and calculated relative to PS standards. ${ }^{e}$ A 1.5 equiv $\left[\mathrm{Me}\left(\mathrm{C}_{18} \mathrm{H}_{37}\right)_{2} \mathrm{~N}-\mathrm{H}\right]^{+}\left[\mathrm{B}\left(\mathrm{C}_{6} \mathrm{~F}_{5}\right)_{4}\right]^{-}$was used. ${ }^{\mathrm{f}}(\mathrm{iBu})_{3} \mathrm{Al}$ was used instead of trioctylaluminum. ${ }^{\mathrm{g}} \mathrm{A} 2.0$ equiv $\left[\mathrm{Me}\left(\mathrm{C}_{18} \mathrm{H}_{37}\right)_{2} \mathrm{~N}-\mathrm{H}\right]^{+}\left[\mathrm{B}\left(\mathrm{C}_{6} \mathrm{~F}_{5}\right)_{4}\right]^{-}$was used. ${ }^{\mathrm{h}}$ The activation reaction time was short $(<3 \mathrm{~min})$.

Activated CGC-Ti species [5- $\left.\mathrm{Ti}\left(-\mathrm{CH}_{2} \mathrm{~N}\left(\mathrm{C}_{18} \mathrm{H}_{37}\right)_{2}\right)\right]^{+}\left[\mathrm{B}\left(\mathrm{C}_{6} \mathrm{~F}_{5}\right)_{4}\right]^{-}$, though it was generated uncleanly with some insoluble and soluble side-products in the overnight reaction of 5-TiMe 2 with 1.0 equiv $\left[\mathrm{Me}\left(\mathrm{C}_{18} \mathrm{H}_{37}\right)_{2} \mathrm{~N}-\mathrm{H}\right]^{+}\left[\mathrm{B}\left(\mathrm{C}_{6} \mathrm{~F}_{5}\right)_{4}\right]^{-}$, exhibited high activity (yield $4.9 \mathrm{~g}$; entry 5), which could be further improved by mitigating the generation of insoluble side-products, using 1.5 equiv (instead of 1.0 equiv) $\left[\mathrm{Me}\left(\mathrm{C}_{18} \mathrm{H}_{37}\right)_{2} \mathrm{~N}-\mathrm{H}\right]^{+}\left[\mathrm{B}\left(\mathrm{C}_{6} \mathrm{~F}_{5}\right)_{4}\right]^{-}$in the activation reaction (yield $6.2 \mathrm{~g}$, entry 6). The species $\left[5-\mathrm{TiCl}\left(\mathrm{N}(\mathrm{H})\left(\mathrm{C}_{18} \mathrm{H}_{37}\right)_{2}\right)\right]^{+}\left[\mathrm{B}\left(\mathrm{C}_{6} \mathrm{~F}_{5}\right)_{4}\right]^{-}$ generated in the reaction of 5- $\mathrm{TiCl}(\mathrm{Me})$ and secondary amine-derived ammonium salt $\left[\left(\mathrm{C}_{18} \mathrm{H}_{37}\right)_{2} \mathrm{NH}_{2}\right]^{+}\left[\mathrm{B}\left(\mathrm{C}_{6} \mathrm{~F}_{5}\right)_{4}\right]^{-}$showed a low yield (1.2 g), which, however, could be improved by replacing trioctylaluminum (fed as a scavenger) with $(\mathrm{iBu})_{3} \mathrm{Al}$, although it was still lower than that of $\left[5-\mathrm{Ti}\left(\mathrm{CH}_{2} \mathrm{~N}\left(\mathrm{C}_{18} \mathrm{H}_{37}\right)_{2}\right)\right]^{+}\left[\mathrm{B}\left(\mathrm{C}_{6} \mathrm{~F}_{5}\right)_{4}\right]^{-}$(4.5 g; entry 7). For initiation of polymerization, [5- $\left.\mathrm{TiCl}\left(\mathrm{N}(\mathrm{H})\left(\mathrm{C}_{18} \mathrm{H}_{37}\right)_{2}\right)\right]^{+}\left[\mathrm{B}\left(\mathrm{C}_{6} \mathrm{~F}_{5}\right)_{4}\right]^{-}$should be alkylated (i.e., should be transformed to $\left.\left[5-\mathrm{TiR}\left(\mathrm{N}(\mathrm{H})\left(\mathrm{C}_{18} \mathrm{H}_{37}\right)_{2}\right)\right]^{+}\left[\mathrm{B}\left(\mathrm{C}_{6} \mathrm{~F}_{5}\right)_{4}\right]^{-}\right)$by the action of $\mathrm{R}_{3} \mathrm{Al}$, which might not be effective with bulky trioctylaluminum but occurred facilely with $(\mathrm{iBu})_{3} \mathrm{Al}$. The activated species $\left[6-\mathrm{Ti}\left(\mathrm{CH}_{2} \mathrm{~N}\left(\mathrm{C}_{18} \mathrm{H}_{37}\right)_{2}\right)\right]^{+}\left[\mathrm{B}\left(\mathrm{C}_{6} \mathrm{~F}_{5}\right)_{4}\right]^{-}$generated during the overnight reaction of tetrahydroquinoline-derived half-metallocene complex 6-TiMe 2 with $\left[\mathrm{Me}\left(\mathrm{C}_{18} \mathrm{H}_{37}\right)_{2} \mathrm{~N}\right.$ $\mathrm{H}]^{+}\left[\mathrm{B}\left(\mathrm{C}_{6} \mathrm{~F}_{5}\right)_{4}\right]^{-}$showed somewhat lower activity than $\left[5-\mathrm{Ti}\left(\mathrm{CH}_{2} \mathrm{~N}\left(\mathrm{C}_{18} \mathrm{H}_{37}\right)_{2}\right)\right]^{+}\left[\mathrm{B}\left(\mathrm{C}_{6} \mathrm{~F}_{5}\right)_{4}\right]^{-}$. In this case, the yield was improved by increasing the amount of $\left[\mathrm{Me}\left(\mathrm{C}_{18} \mathrm{H}_{37}\right)_{2} \mathrm{~N}-\mathrm{H}\right]^{+}$ $\left[\mathrm{B}\left(\mathrm{C}_{6} \mathrm{~F}_{5}\right)_{4}\right]^{-}$used in the activation reaction $(4.4,5.3$, and $5.8 \mathrm{~g}$ for $1.0,1.5$, and 2.0 equiv, respectively; entries 8-10). The species $\left[6-\mathrm{Ti}\left(\mathrm{N}_{(}\left(\mathrm{C}_{18} \mathrm{H}_{37}\right)_{2}\right)\right]^{+}\left[\mathrm{B}\left(\mathrm{C}_{6} \mathrm{~F}_{5}\right)_{4}\right]^{-}$generated in the reaction of 6-TiMe 2 and secondary amine-derived ammonium salt $\left[\left(\mathrm{C}_{18} \mathrm{H}_{37}\right)_{2} \mathrm{NH}_{2}\right]^{+}\left[\mathrm{B}\left(\mathrm{C}_{6} \mathrm{~F}_{5}\right)_{4}\right]^{-}$ was inactive. Species $\left[6-\mathrm{TiCl}\left(\mathrm{N}(\mathrm{H})\left(\mathrm{C}_{18} \mathrm{H}_{37}\right)_{2}\right)\right]^{+}\left[\mathrm{B}\left(\mathrm{C}_{6} \mathrm{~F}_{5}\right)_{4}\right]^{-}$generated from 6-TiCl(Me) showed a lower yield than $\left[6-\mathrm{Ti}\left(\mathrm{CH}_{2} \mathrm{~N}\left(\mathrm{C}_{18} \mathrm{H}_{37}\right)_{2}\right)\right]^{+}\left[\mathrm{B}\left(\mathrm{C}_{6} \mathrm{~F}_{5}\right)_{4}\right]^{-}$(4.2 g; entry 12). The activated species $\left[7-\mathrm{Ti}\left(\mathrm{CH}_{2} \mathrm{~N}\left(\mathrm{C}_{18} \mathrm{H}_{37}\right)_{2}\right)\right]^{+}\left[\mathrm{B}\left(\mathrm{C}_{6} \mathrm{~F}_{5}\right)_{4}\right]^{-}$exhibited a similar performance to that of $\left[6-\mathrm{Ti}\left(\mathrm{CH}_{2} \mathrm{~N}\left(\mathrm{C}_{18} \mathrm{H}_{37}\right)_{2}\right)\right]^{+}\left[\mathrm{B}\left(\mathrm{C}_{6} \mathrm{~F}_{5}\right)_{4}\right]^{-}$(entries 14-15). By feeding the activated species 
[7- $\left.\mathrm{Ti}(\mathrm{Me})\left(\mathrm{NMe}\left(\mathrm{C}_{18} \mathrm{H}_{37}\right)_{2}\right)\right]^{+}\left[\mathrm{B}\left(\mathrm{C}_{6} \mathrm{~F}_{5}\right)_{4}\right]^{-}$as soon as it was prepared prior to transformation to $\left[7-\mathrm{Ti}\left(\mathrm{CH}_{2} \mathrm{~N}\left(\mathrm{C}_{18} \mathrm{H}_{37}\right)_{2}\right)\right]^{+}\left[\mathrm{B}\left(\mathrm{C}_{6} \mathrm{~F}_{5}\right)_{4}\right]^{-}$, yield was improved (5.6 g vs. $4.1 \mathrm{~g}$; entry 13 vs. 14$)$. It is worth mentioning that less amounts of polymers were gained under the identical polymerization conditions when $7-\mathrm{TiMe}_{2}$ was activated with $\left[\mathrm{Me}\left(\mathrm{C}_{18} \mathrm{H}_{37}\right)_{2} \mathrm{~N}-\mathrm{H}\right]^{+}\left[\mathrm{B}\left(\mathrm{C}_{6} \mathrm{~F}_{5}\right)_{4}\right]^{-}$ that was prepared by the conventional salt metathesis method (5.6 g vs. $5.2 \mathrm{~g}, 5.1 \mathrm{~g}, 5.1 \mathrm{~g}$, and $4.5 \mathrm{~g}$ for the ones of which ${ }^{1} \mathrm{H}$ NMR spectra are shown in Figure 1a-d, respectively).

A low-molecular-weight polymer was generated with $\left[1-\mathrm{Zr}(\mathrm{Me})\left(\mathrm{NMe}\left(\mathrm{C}_{18} \mathrm{H}_{37}\right)_{2}\right)\right]^{+}$ $\left[\mathrm{B}\left(\mathrm{C}_{6} \mathrm{~F}_{5}\right)_{4}\right]^{-}\left(M_{\mathrm{W}}, 32 \mathrm{kDa}\right)$, and bimodal-molecular-weight distribution was observed with high dispersity value $\left(M_{\mathrm{w}} / M_{\mathrm{n}}, 13\right)$ (entry 1$)$, which inferred that structure of the active species was not persistent during the polymerization especially due to the severe temperature rising. Much-higher-molecular-weight polymers were generated from 3- and 4-Hf species $\left(M_{\mathrm{w}}, 700-800 \mathrm{kDa}\right)$ with much broader multimodal-molecular-weight distributions $\left(M_{\mathrm{w}} / M_{\mathrm{n}}, 40-80\right)$, which also might be due to temperature rising (entries 2-4). From a typical CGC [5-Ti( $\left.\left(\mathrm{CH}_{2} \mathrm{~N}\left(\mathrm{C}_{18} \mathrm{H}_{37}\right)_{2}\right)\right]^{+}\left[\mathrm{B}\left(\mathrm{C}_{6} \mathrm{~F}_{5}\right)_{4}\right]^{-}$, polymers with b-modal-molecular-weight distributions were also generated $\left(M_{\mathrm{w}} / M_{\mathrm{n}}, 13\right.$ and 7.3) with $M_{\mathrm{w}}$ values of 150 and $100 \mathrm{kDa}$ (entries 5 and 6). However, a polymer with relatively narrow and unimodal-molecularweight distribution was generated with $\left[5-\mathrm{TiCl}\left(\mathrm{N}(\mathrm{H})\left(\mathrm{C}_{18} \mathrm{H}_{37}\right)_{2}\right)\right]^{+}\left[\mathrm{B}\left(\mathrm{C}_{6} \mathrm{~F}_{5}\right)_{4}\right]^{-}\left(M_{\mathrm{W}}, 210\right.$, $\left.M_{\mathrm{w}} / M_{\mathrm{n}}, 3.6\right)$ (entry 7), which might be attributed to relatively lower polymerization temperature (90-115 $\left.{ }^{\circ} \mathrm{C}\right)$; it has been known that the typical CGC 5-Ti species did not exhibit thermal stability above $110{ }^{\circ} \mathrm{C}$ [27]. In contrast, half-metallocene 6-Ti and 7-Ti species generated polymers with unimodal-molecular-weight distributions in all cases even when polymerization temperature exceeded $120{ }^{\circ} \mathrm{C}\left(M_{\mathrm{W}}, 210-340 \mathrm{kDa} ; M_{\mathrm{w}} / M_{\mathrm{n}}\right.$, 2.3-3.5) (entries 8-15).

\section{Materials and Methods}

All the experiments were performed in an inert atmosphere, using a standard glove box (KOREA KIYON, Seoul, Korea) and Schlenk techniques. Toluene, hexane, diethyl ether, and THF were distilled from benzophenone ketyl. Hexane used for the polymerization reactions was purchased from Thermo Fischer Scientific (Seoul, Korea) and purified over an $\mathrm{Na} / \mathrm{K}$ alloy. Sublimed-grade $\mathrm{HfCl}_{4}$ was purchased from Strem (Newburyport, MA, USA) and used as received. ${ }^{1} \mathrm{H}$ NMR $(600 \mathrm{MHz}),{ }^{13} \mathrm{C}$ NMR $(150 \mathrm{MHz})$, and ${ }^{19} \mathrm{~F}$ NMR $(564 \mathrm{MHz})$ analyses were performed by using a JEOL ECZ 600 instrument. Elemental analyses were performed at the Analytical Center of Ajou University. The GPC data were obtained in 1,2,4-trichlorobenzene at $160^{\circ} \mathrm{C}$, using a PL-GPC 220 system equipped with an RI detector (HLC-8321 GPC/HT RI detector (Tosoh)) and two columns (PLgel mixed-B $7.5 \times 300 \mathrm{~mm}$ from Varian (Polymer Lab)). We obtained $1-\mathrm{ZrMe}_{2}, 2-\mathrm{ZrMe}_{2}$, and $5-\mathrm{TiMe}_{2}$ from Precious Catalysts Inc, and 3-HfMe [52], 4- $-\mathrm{HfMe}_{2}$ [53], 6- -TiMe 2 [41], and 7-TiMe 2 [54] were prepared according to a previously reported method.

\subsection{Preparation of $\left(\left[\mathrm{Me}\left(\mathrm{C}_{18} \mathrm{H}_{37}\right)_{2} \mathrm{~N}-\mathrm{H}\right]^{+}\left[\mathrm{B}\left(\mathrm{C}_{6} \mathrm{~F}_{5}\right)_{4}\right]^{-},\left[\left(\mathrm{C}_{12} \mathrm{H}_{25}\right)_{3} \mathrm{~N}-\mathrm{H}\right]^{+}\left[\mathrm{B}\left(\mathrm{C}_{6} \mathrm{~F}_{5}\right)_{4}\right]^{-}\right.$, and $\left[\left(\mathrm{C}_{18} \mathrm{H}_{37}\right)_{2} \mathrm{NH}_{2}\right]^{+}\left[B\left(\mathrm{C}_{6} \mathrm{~F}_{5}\right)_{4}\right]^{-}$}

$\left[\mathrm{PhN}(\mathrm{Me})_{2}-\mathrm{H}\right]^{+}\left[\mathrm{B}\left(\mathrm{C}_{6} \mathrm{~F}_{5}\right)_{4}\right]^{-}(2.00 \mathrm{~g}, 2.50 \mathrm{mmol})$ was added to $\mathrm{Me}\left(\mathrm{C}_{18} \mathrm{H}_{37}\right)_{2} \mathrm{~N}(1.34 \mathrm{~g}$, $2.50 \mathrm{mmol})$ in anhydrous toluene $(20 \mathrm{~g})$. After stirring overnight at room temperature, the solution was filtered over Celite to obtain a completely clear solution. The solvent was removed under vacuum. Mineral spirit $\left(30 \mathrm{~g}\right.$, b.p., $\left.194^{\circ} \mathrm{C}\right)$ was added and volatiles were completely removed by distillation at $50{ }^{\circ} \mathrm{C}$ under full vacuum to obtain a clear, dark olive-green oil $(3.00 \mathrm{~g}, 100 \%) .{ }^{1} \mathrm{H} \mathrm{NMR}\left(\mathrm{C}_{6} \mathrm{D}_{6}\right): \delta 3.17(\mathrm{br}, 1 \mathrm{H}, \mathrm{NH}), 1.97\left(\mathrm{~m}, 2 \mathrm{H}, \mathrm{NCH}_{2}\right)$, $1.79\left(\mathrm{~m}, 2 \mathrm{H}, \mathrm{NCH}_{2}\right), 1.50\left(\mathrm{~d}, J=4.8 \mathrm{~Hz}, 3 \mathrm{H}, \mathrm{NCH}_{3}\right), 1.47-1.29(\mathrm{~m}, 48 \mathrm{H}), 1.26$ (quintet, $J=7.8 \mathrm{~Hz}, 4 \mathrm{H}$ ), 1.12 (quintet, $J=7.8 \mathrm{~Hz}, 4 \mathrm{H}), 0.94(\mathrm{t}, J=7.2 \mathrm{~Hz}, 6 \mathrm{H}), 0.87$ (quintet, $J=7.2 \mathrm{~Hz}$, $4 \mathrm{H}), 0.80(\mathrm{~m}, 4 \mathrm{H}) \mathrm{ppm} .{ }^{19} \mathrm{~F}$ NMR $\left(\mathrm{C}_{6} \mathrm{D}_{6}\right): \delta-132.22$ (ortho- $\left.\mathrm{C}_{6} \mathrm{~F}_{5}\right),-161.72(\mathrm{t}, J=25.9 \mathrm{~Hz}$, para- $\left.\mathrm{C}_{6} \mathrm{~F}_{5}\right),-165.95$ (brt, meta- $\mathrm{C}_{6} \mathrm{~F}_{5}$ ) ppm.

$\left[\left(\mathrm{C}_{12} \mathrm{H}_{25}\right)_{3} \mathrm{~N}-\mathrm{H}\right]^{+}\left[\mathrm{B}\left(\mathrm{C}_{6} \mathrm{~F}_{5}\right)_{4}\right]^{-}$was prepared by using the same procedure and experimental conditions, using tridodecylamine $\left(\mathrm{C}_{12} \mathrm{H}_{25}\right)_{3} \mathrm{~N}$ (yield, 96\%). ${ }^{1} \mathrm{H}$ NMR $\left(\mathrm{C}_{6} \mathrm{D}_{6}\right): \delta 3.70$ (br, $1 \mathrm{H}, \mathrm{NH}$ ), 2.19 (br, $\left.6 \mathrm{H}, \mathrm{NCH}_{2}\right), 1.42-1.30(\mathrm{~m}, 36 \mathrm{H}), 1.26$ (quintet, $\left.J=6.6 \mathrm{~Hz}, 6 \mathrm{H}\right), 1.16$ 
(quintet, $J=6.0 \mathrm{~Hz}, 6 \mathrm{H}), 1.04-0.92(\mathrm{~m}, 21 \mathrm{H}) \mathrm{ppm} .{ }^{19} \mathrm{~F} \mathrm{NMR}\left(\mathrm{C}_{6} \mathrm{D}_{6}\right): \delta-131.95$ (ortho- $\mathrm{C}_{6} \mathrm{~F}_{5}$ ), $-161.72\left(\mathrm{t}, J=21.4 \mathrm{~Hz}\right.$, para- $\left.\mathrm{C}_{6} \mathrm{~F}_{5}\right),-165.91\left(\mathrm{brt}, J=17.5 \mathrm{~Hz}\right.$, meta- $\left.\mathrm{C}_{6} \mathrm{~F}_{5}\right) \mathrm{ppm} .{ }^{13} \mathrm{C}$ NMR $\left(\mathrm{C}_{6} \mathrm{D}_{6}\right): \delta 149.05\left(\mathrm{~d}, J=241.2 \mathrm{~Hz}\right.$, ortho- $\left.\mathrm{C}_{6} \mathrm{~F}_{5}\right), 138.98\left(\mathrm{~d}, J=244.2 \mathrm{~Hz}\right.$, para- $\left.\mathrm{C}_{6} \mathrm{~F}_{5}\right), 137.08$ $\left(\mathrm{d}, J=247.1 \mathrm{~Hz}\right.$, meta- $\left.\mathrm{C}_{6} \mathrm{~F}_{5}\right), 124.80\left(\mathrm{br}\right.$, ipso $\left.-\mathrm{C}_{6} \mathrm{~F}_{5}\right), 54.39\left(\mathrm{NCH}_{2}\right), 32.37,30.12,29.88(\mathrm{~d}$, $J=8.6 \mathrm{~Hz}), 29.67,29.17,26.19,24.09,23.15,14.33 \mathrm{ppm}$.

$\left[\left(\mathrm{C}_{18} \mathrm{H}_{37}\right)_{2} \mathrm{NH}_{2}\right]^{+}\left[\mathrm{B}\left(\mathrm{C}_{6} \mathrm{~F}_{5}\right)_{4}\right]^{-}$was also prepared by the same procedure and experimental conditions, using dioctadecylamine $\left(\mathrm{C}_{18} \mathrm{H}_{37}\right)_{2} \mathrm{NH}$ (yield, $\left.100 \%\right) .{ }^{1} \mathrm{H}$ NMR $\left(\mathrm{C}_{6} \mathrm{D}_{6}\right): \delta$ $3.11\left(\mathrm{br}, 2 \mathrm{H}, \mathrm{NH}_{2}\right), 1.80\left(\mathrm{br}, 4 \mathrm{H}, \mathrm{NCH}_{2}\right), 1.47-1.26(\mathrm{~m}, 48 \mathrm{H}), 1.22$ (quintet, $\left.J=7.2 \mathrm{~Hz}, 4 \mathrm{H}\right)$, 1.10 (quintet, $J=7.2 \mathrm{~Hz}, 4 \mathrm{H}), 0.93(\mathrm{t}, J=7.2 \mathrm{~Hz}, 6 \mathrm{H}), 0.84$ (quintet, $J=7.2 \mathrm{~Hz}, 4 \mathrm{H}$ ), 0.74 $(\mathrm{m}, 4 \mathrm{H}) \mathrm{ppm} .{ }^{19} \mathrm{~F}$ NMR $\left(\mathrm{C}_{6} \mathrm{D}_{6}\right): \delta-132.16$ (ortho- $\left.\mathrm{C}_{6} \mathrm{~F}_{5}\right),-161.70\left(\mathrm{t}, J=22.0 \mathrm{~Hz}\right.$, para $\left.-\mathrm{C}_{6} \mathrm{~F}_{5}\right)$, -165.97 (brt, $J=17.5 \mathrm{~Hz}$, meta- $\left.\mathrm{C}_{6} \mathrm{~F}_{5}\right)$ ppm. ${ }^{13} \mathrm{C}$ NMR $\left(\mathrm{C}_{6} \mathrm{D}_{6}\right): \delta 149.05(\mathrm{~d}, J=238.5 \mathrm{~Hz}$, ortho- $\left.\mathrm{C}_{6} \mathrm{~F}_{5}\right), 138.96\left(\mathrm{~d}, J=245.7 \mathrm{~Hz}\right.$, para- $\left.\mathrm{C}_{6} \mathrm{~F}_{5}\right), 137.10\left(\mathrm{~d}, J=248.5 \mathrm{~Hz}\right.$, meta- $\left.\mathrm{C}_{6} \mathrm{~F}_{5}\right), 124.73$ (br, ipso- $\left.\mathrm{C}_{6} \mathrm{~F}_{5}\right), 49.52\left(\mathrm{NCH}_{2}\right), 32.39,30.25(\mathrm{~m}), 29.89(\mathrm{~d}, J=5.7 \mathrm{~Hz}), 29.63,29.05,25.95(\mathrm{~d}$, $J=11.4 \mathrm{~Hz}), 23.15,14.35 \mathrm{ppm}$.

\subsection{Preparation of 4-HfMe 2 and 3-HfMe}

First, $\mathrm{nBuLi}(1.07 \mathrm{~mL}, 2.5 \mathrm{M}$ in hexane, $2.68 \mathrm{mmol})$ was diluted with hexane $(1.4 \mathrm{~mL})$ and added dropwise to a stirred suspension of 2,7-di-tert-butyl-9-(cyclopentadienyldiphenyl methyl)-9H-fluorene $\left(4-\mathrm{H}_{2}, 0.661 \mathrm{~g}, 1.30 \mathrm{mmol}\right)$ in diethyl ether $(28 \mathrm{~mL})$ at $-78^{\circ} \mathrm{C}$. After the suspension was stirred overnight at room temperature, the solvent was removed, using a vacuum line. The residue was washed with hexane $(20 \mathrm{~mL})$ to obtain a light red solid $(0.643 \mathrm{~g}, 95 \%)$, which was identified as $4-\mathrm{Li}_{2}$ by ${ }^{1} \mathrm{H}$ NMR analysis. The isolated solid $(0.784 \mathrm{~g}, 1.51 \mathrm{mmol})$ was dissolved in THF $(14 \mathrm{~mL})$, cooled at $-30^{\circ} \mathrm{C}$, and $\operatorname{MeMgBr}(1.00 \mathrm{~g}$, $3.28 \mathrm{M}$ in diethyl ether; density $=1.035 \mathrm{~g} / \mathrm{mL}, 3.17 \mathrm{mmol})$ and $\mathrm{HfCl}_{4}(0.473 \mathrm{~g}, 1.48 \mathrm{mmol})$ were successively added. After stirring overnight at room temperature, the solvent was removed, using a vacuum line. The residue was extracted by using hot hexane $(35 \mathrm{~mL})$. The filtrate was allowed to stand at $-30{ }^{\circ} \mathrm{C}$ for $1 \mathrm{~d}$ to deposit yellow crystals that were analytically pure and suitable for $\mathrm{X}$-ray crystallography $(0.45 \mathrm{~g}, 41 \%) .{ }^{1} \mathrm{H} \mathrm{NMR}\left(\mathrm{C}_{6} \mathrm{D}_{6}\right): \delta$ $8.03(\mathrm{~d}, J=8.4 \mathrm{~Hz}, 2 \mathrm{H}), 7.89(\mathrm{~d}, J=7.8 \mathrm{~Hz}, 2 \mathrm{H}), 7.70(\mathrm{~d}, J=7.8 \mathrm{~Hz}, 2 \mathrm{H}), 7.45(\mathrm{dd}, J=8.4$, $1.8 \mathrm{~Hz}, 2 \mathrm{H}), 7.13(\mathrm{td}, J=7.8,1.2 \mathrm{~Hz}, 2 \mathrm{H}), 7.05(\mathrm{td}, J=7.8,1.2 \mathrm{~Hz}, 2 \mathrm{H}), 6.95(\mathrm{t}, J=7.8 \mathrm{~Hz}, 2 \mathrm{H})$, $6.45(\mathrm{~s}, 2 \mathrm{H}), 6.11(\mathrm{t}, J=3.0 \mathrm{~Hz}, 2 \mathrm{H}), 5.56(\mathrm{t}, J=3.0 \mathrm{~Hz}, 2 \mathrm{H}), 1.11(\mathrm{~s}, 18 \mathrm{H}),-1.35\left(\mathrm{~s}, \mathrm{Hf}\left(\mathrm{CH}_{3}\right)_{2}\right.$, $6 \mathrm{H}) \mathrm{ppm} .{ }^{13} \mathrm{C}$ NMR $\left(\mathrm{C}_{6} \mathrm{D}_{6}\right): \delta 148.69,146.44,130.15,128.84,128.70,127.03,126.70,123.86$, $123.28,121.42,119.31,116.76,112.22,108.21,101.99,77.13,58.34,38.91,35.09,31.12 \mathrm{ppm}$. Anal. Calcd. $\left(\mathrm{C}_{41} \mathrm{H}_{44} \mathrm{Hf}\right)$ : C, 68.85; H, 6.20\%. Found: $\mathrm{C}, 68.47 ; \mathrm{H}, 6.50 \%$.

Complex 3 was prepared by using the same procedure and experimental conditions with $3-\mathrm{H}_{2} .{ }^{1} \mathrm{H}$ NMR $\left(\mathrm{C}_{6} \mathrm{D}_{6}\right): \delta 8.40(\mathrm{~d}, J=1.8 \mathrm{~Hz}, 2 \mathrm{H}), 7.87(\mathrm{~d}, J=7.8 \mathrm{~Hz}, 2 \mathrm{H}), 7.77(\mathrm{~d}$, $J=8.4 \mathrm{~Hz}, 2 \mathrm{H}), 7.15(\mathrm{td}, J=7.8,1.4 \mathrm{~Hz}, 2 \mathrm{H}), 7.03(\mathrm{td}, J=6.0,1.4 \mathrm{~Hz}, 2 \mathrm{H}), 6.97(\mathrm{t}, J=7.2 \mathrm{~Hz}$, $2 \mathrm{H}), 6.85(\mathrm{dd}, J=9.3,1.8 \mathrm{~Hz}, 2 \mathrm{H}), 6.41(\mathrm{~d}, J=9.6 \mathrm{~Hz}, 2 \mathrm{H}), 6.10(\mathrm{t}, J=2.4 \mathrm{~Hz}, 2 \mathrm{H}), 5.47(\mathrm{t}$, $J=3.0 \mathrm{~Hz}, 2 \mathrm{H}), 1.35(\mathrm{~s}, 18 \mathrm{H}),-1.37\left(\mathrm{~s}, \mathrm{Hf}\left(\mathrm{CH}_{3}\right)_{2}, 6 \mathrm{H}\right) \mathrm{ppm} .{ }^{13} \mathrm{C}$ NMR $\left(\mathrm{C}_{6} \mathrm{D}_{6}\right): \delta 146.81$, $146.55,130.13,128.97,128.74,127.28,126.79,126.09,123.27,121.98,118.94,118.78,112.32$, $109.04,102.78,77.52,58.73,39.15,34.98,32.04$ ppm. Anal. Calcd. $\left(\mathrm{C}_{41} \mathrm{H}_{44} \mathrm{Hf}\right): \mathrm{C}, 68.85 ; \mathrm{H}$, $6.20 \%$. Found: C, 68.56; H, 6.42\%.

\subsection{Preparation of 5-TiCl(Me) and 6-TiCl(Me)}

$\mathrm{ZnCl}_{2}(20.8 \mathrm{mg}, 0.153 \mathrm{mmol})$ was added to $5-\mathrm{TiMe}_{2}(100 \mathrm{mg}, 0.305 \mathrm{mmol})$ in anhydrous toluene ( $2 \mathrm{~mL}$ ). Insoluble $\mathrm{ZnCl}_{2}$ gradually disappeared, and an almost-clear solution was obtained after stirring for several hours at room temperature. After removing cloudy, insoluble fractions via filtration, the solvent was removed, using a vacuum line, to obtain a yellow solid. An analytically pure compound was obtained by recrystallization in hexane at $-30{ }^{\circ} \mathrm{C}$. Yellow cubic-shaped crystals suitable for $\mathrm{X}$-ray crystallography were isolated (80 mg, 76\%). ${ }^{1} \mathrm{H}$ NMR $\left(\mathrm{C}_{6} \mathrm{D}_{6}\right): \delta 2.01(\mathrm{~s}, 3 \mathrm{H}), 1.96(\mathrm{~s}, 3 \mathrm{H}), 1.92(\mathrm{~s}, 3 \mathrm{H}), 1.90(\mathrm{~s}, 3 \mathrm{H}), 1.51(\mathrm{~s}$, 9H), $0.84(\mathrm{~s}, 3 \mathrm{H}), 0.46(\mathrm{~s}, 3 \mathrm{H}), 0.38(\mathrm{~s}, 3 \mathrm{H}) \mathrm{ppm} .{ }^{13} \mathrm{C} \mathrm{NMR}\left(\mathrm{C}_{6} \mathrm{D}_{6}\right): \delta 136.49,134.56,133.43$, $132.72,101.56,59.59,53.31,33.90,15.48,15.11,12.68,12.11,5.86(\mathrm{~d}, J=5.7 \mathrm{~Hz}) \mathrm{ppm}$. Anal. Calcd. $\left(\mathrm{C}_{16} \mathrm{H}_{30} \mathrm{ClNSiTi}\right): \mathrm{C}, 55.25 ; \mathrm{H}, 8.69 ; \mathrm{N}, 4.03 \%$. Found: $\mathrm{C}, 55.54 ; \mathrm{H}, 8.91 ; \mathrm{N}, 3.73 \%$. 
Using 6- $\mathrm{TiMe}_{2}, 6-\mathrm{TiCl}(\mathrm{Me})$ was prepared with the same procedure and experimental conditions. Red needle-shaped crystals were isolated $(90 \mathrm{mg}, 85 \%) .{ }^{1} \mathrm{H} \mathrm{NMR}\left(\mathrm{C}_{6} \mathrm{D}_{6}\right): \delta 6.98$ $(\mathrm{m}, 1 \mathrm{H}), 6.88(\mathrm{~m}, 2 \mathrm{H}), 4.72(\mathrm{ddd}, J=7.2,3.6 \mathrm{~Hz}, 1 \mathrm{H}), 4.28(\mathrm{ddd}, J=8.4,3.0 \mathrm{~Hz}, 1 \mathrm{H}), 2.31$ $(\mathrm{t}, J=6.6 \mathrm{~Hz}, 2 \mathrm{H}), 2.04(\mathrm{~s}, 3 \mathrm{H}), 1.95(\mathrm{~s}, 3 \mathrm{H}), 1.77(\mathrm{~s}, 3 \mathrm{H}), 1.62(\mathrm{~s}, 3 \mathrm{H}), 1.54(\mathrm{~m}, 2 \mathrm{H}), 0.90(\mathrm{~s}$, $3 \mathrm{H}) \mathrm{ppm} .{ }^{13} \mathrm{C}$ NMR $\left(\mathrm{C}_{6} \mathrm{D}_{6}\right): \delta 161.68,139.63,137.07,136.91,129.11,128.92,126.72,124.78$, $123.90,121.44,120.29,54.40,51.04,26.71,22.51,12.48,12.22,11.91,11.85$ ppm. Anal. Calcd. $\left(\mathrm{C}_{19} \mathrm{H}_{24} \mathrm{ClNTi}\right): \mathrm{C}, 65.25 ; \mathrm{H}, 6.92 ; \mathrm{N}, 4.01 \%$. Found: $\mathrm{C}, 65.53 ; \mathrm{H}, 7.30 ; \mathrm{N}, 3.75 \%$.

\subsection{A Representative Activation Reaction}

First 4- $\mathrm{HfMe}_{2}(7.15 \mathrm{mg}, 10.0 \mu \mathrm{mol})$ dissolved in $\mathrm{C}_{6} \mathrm{D}_{12}$ was added to a solution of $\left[\mathrm{Me}\left(\mathrm{C}_{18} \mathrm{H}_{37}\right)_{2} \mathrm{~N}-\mathrm{H}\right]^{+}\left[\mathrm{B}\left(\mathrm{C}_{6} \mathrm{~F}_{5}\right)_{4}\right]^{-}(12.2 \mathrm{mg}, 10.0 \mu \mathrm{mol})$ in $\mathrm{C}_{6} \mathrm{D}_{12}$ in an NMR tube. After sealing the tube, the activation reaction was monitored, using ${ }^{1} \mathrm{H}$ NMR spectroscopy. After finishing the ${ }^{1} \mathrm{H}$ NMR studies, the solution was completely transferred to a vial and diluted with cyclohexane to obtain $5.29 \mu \mathrm{mol}-\mathrm{Hf} / \mathrm{g}$ stock solution, which was used in the polymerization studies.

\subsection{A Representative Polymerization Procedure (Entry 4)}

In a glove box, a dried bomb reactor $(75 \mathrm{~mL})$ was charged with hexane (15.5 $\mathrm{g}), 1$ octene $(5.00 \mathrm{~g})$, and trioctylaluminum $(12.1 \mathrm{~g}, 33.0 \mu \mathrm{mol})$. The reactor was then assembled and removed from the glove box. The bomb reactor was immersed in a bath at $110{ }^{\circ} \mathrm{C}$. When the temperature inside the bomb reactor reached $65^{\circ} \mathrm{C}$, a catalyst stock solution containing $\left[4-\mathrm{Hf}(\mathrm{Me})\left(\mathrm{NMe}\left(\mathrm{C}_{18} \mathrm{H}_{37}\right)_{2}\right)\right]^{+}\left[\mathrm{B}\left(\mathrm{C}_{6} \mathrm{~F}_{5}\right)_{4}\right]^{-}(1.00 \mu \mathrm{mol})$ was injected. After catalyst feeding, ethylene gas was immediately charged under a pressure of 20 bar. The temperature immediately started to rise, reaching $159^{\circ} \mathrm{C}$ in $3 \mathrm{~min}$. The polymerization was performed for 15 min under a constant ethylene pressure of 20 bar while monitoring the temperature in an isothermal bath at $110^{\circ} \mathrm{C}$. In some cases (entries 2-3, 7-10, and 14), polymerization was not initiated until temperature reaching some threshold, in which cases polymerization reaction was performed for 15 min counted from the initiation point. The reactor was cooled with an ice bath and the ethylene gas was vented off. The generated polymer was isolated by removing the solvent under vacuum at $130{ }^{\circ} \mathrm{C}$ for $2 \mathrm{~h}(5.41 \mathrm{~g})$.

\subsection{X-ray Crystallography}

Specimens of suitable quality and size were selected, mounted, and centered in the X-ray beam, using a video camera. Reflection data were collected at $100 \mathrm{~K}$ on an APEX II CCD area diffractometer (Bruker), using graphite-monochromated Mo K $\alpha$ radiation $(\lambda=0.7107 \AA$ А $)$. The hemisphere of the reflection data was collected as $\varphi$ and $\omega$ scan frames at $0.5^{\circ}$ per frame and an exposure time of $10 \mathrm{~s}$ per frame. The cell parameters were determined and refined by using the SMART program. Data reduction was performed by using SAINT software. The data were corrected for Lorentz and polarization effects. Empirical absorption correction was applied by using the SADABS program. The structure was solved by using direct methods and refined with the full matrix least-squares method, using the SHELXTL package and the olex2 program with anisotropic thermal parameters for all non-hydrogen atoms.

The crystallographic data for 4-HfMe $2 \cdot 0.4$ (toluene) (CCDC\# 2070013) that were used in all calculations were as follows: $\mathrm{C}_{87.6} \mathrm{H}_{94.4} \mathrm{Hf}_{2}, \mathrm{M}=1504.21$, triclinic, $a=15.1760(2), b=15.9555(2)$, $c=17.8025(3) \AA, \alpha=63.5766(6)^{\circ}, \beta=69.4527(8)^{\circ}, \gamma=81.8613(7), V=3614.24(9) \AA^{3}$, space group $P-1, Z=2, \rho_{\text {calc }}\left(\mathrm{g} / \mathrm{cm}^{3}\right)=1.382, \mu\left(\mathrm{mm}^{-1}\right)=2.914, \mathrm{~F}(000)=1528$, number of reflections collected $=49,830$, restraints $=178$, parameters $=869$, and number of unique reflections $=13,827$ (R(int) $=0.0605)$. The final GOF, $R_{1}$, and $w R_{2}$ were $1.032,0.0400$, and $0.0828(\mathrm{I}>2 \sigma(\mathrm{I})$ ), respectively.

The crystallographic data for 5- TiCl(Me) (CCDC\# 2070015) that were used in all calculations were as follows: $\mathrm{C}_{16} \mathrm{H}_{30} \mathrm{ClNSiTi}, M=347.82$, monoclinic, $a=13.3706(9), b=12.1586(8)$, $c=11.5983(8) \AA, \beta=90.542(2)^{\circ}, V=1885.4(2) \AA^{3}$, space group $P 2_{1} / \mathrm{c}, Z=4, \rho_{\text {calc }}\left(\mathrm{g} / \mathrm{cm}^{3}\right)$ $=1.225, \mu\left(\mathrm{mm}^{-1}\right)=0.651, \mathrm{~F}(000)=744$, number of reflections collected $=19,653$, restraints 
$=30$, parameters $=242$, and number of unique reflections $=3569(\mathrm{R}(\mathrm{int})=0.0827)$. The final GOF, $R_{1}$, and $w R_{2}$ were $1.070,0.0520$, and $0.1335(\mathrm{I}>2 \sigma(\mathrm{I}))$, respectively.

The crystallographic data for 6-TiCl(Me) (CCDC\# 2070014) that were used in all calculations were as follows: $\mathrm{C}_{19} \mathrm{H}_{24} \mathrm{ClNTi}, M=349.56$, orthorhombic, $a=13.3739$ (3), $b=17.6098(3), c=14.9636(3) \AA, V=3524.10(12) \AA^{3}$, space group $P \mathrm{bca}, Z=8, \rho_{\text {calc }}\left(\mathrm{g} / \mathrm{cm}^{3}\right)$ $=1.318, \mu\left(\mathrm{mm}^{-1}\right)=0.634, \mathrm{~F}(000)=1472$, number of reflections collected $=44,800$, restraints $=12$, parameters $=225$, and number of unique reflections $=3348(\mathrm{R}(\mathrm{int})=0.1804)$. The final GOF, $R_{1}$, and $w R_{2}$ were $1.031,0.0587$, and $0.1179(\mathrm{I}>2 \sigma(\mathrm{I}))$, respectively.

\section{Conclusions}

High-purity tertiary or secondary ammonium tetrakis(pentafluorophenyl)borate ([Me $\left.\left(\mathrm{C}_{18} \mathrm{H}_{37}\right)_{2} \mathrm{~N}-\mathrm{H}\right]^{+}\left[\mathrm{B}\left(\mathrm{C}_{6} \mathrm{~F}_{5}\right)_{4}\right]^{-},\left[\left(\mathrm{C}_{12} \mathrm{H}_{25}\right)_{3} \mathrm{~N}-\mathrm{H}\right]^{+}\left[\mathrm{B}\left(\mathrm{C}_{6} \mathrm{~F}_{5}\right)_{4}\right]^{-}$, and $\left.\left[\left(\mathrm{C}_{18} \mathrm{H}_{37}\right)_{2} \mathrm{NH}_{2}\right]^{+}\left[\mathrm{B}\left(\mathrm{C}_{6} \mathrm{~F}_{5}\right)_{4}\right]^{-}\right)$ containing neither water nor $\mathrm{Cl}^{-}$salt impurities were prepared by the acid-base reaction of $\left[\mathrm{PhN}(\mathrm{Me})_{2}-\mathrm{H}\right]^{+}\left[\mathrm{B}\left(\mathrm{C}_{6} \mathrm{~F}_{5}\right)_{4}\right]^{-}$with the corresponding amine. The action of $\left[\mathrm{Me}\left(\mathrm{C}_{18} \mathrm{H}_{37}\right)_{2} \mathrm{~N}-\right.$ $\mathrm{H}]^{+}\left[\mathrm{B}\left(\mathrm{C}_{6} \mathrm{~F}_{5}\right)_{4}\right]^{-}$on typical ansa-metallocene complexes rac-[ethylenebis(tetrahydroindenyl)] $\mathrm{Zr}(\mathrm{Me})_{2}\left(\mathbf{1}-\mathrm{ZrMe}_{2}\right),\left[\mathrm{Ph}_{2} \mathrm{C}(\mathrm{Cp})\left(3,6-{ }^{t} \mathrm{Bu}_{2} \mathrm{Flu}\right)\right] \mathrm{Hf}(\mathrm{Me})_{2}\left(3-\mathrm{HfMe}_{2}\right)$, and $\left(\left[\mathrm{Ph}_{2} \mathrm{C}(\mathrm{Cp})\left(2,7-{ }^{t} \mathrm{Bu}_{2} \mathrm{Flu}\right)\right]\right.$ $\mathrm{Hf}(\mathrm{Me})_{2}(4-\mathrm{HfMe})_{2}$ afforded clean $\left[\mathrm{L}-\mathrm{M}(\mathrm{Me})\left(\mathrm{NMe}\left(\mathrm{C}_{18} \mathrm{H}_{37}\right)_{2}\right)\right]^{+}\left[\mathrm{B}\left(\mathrm{C}_{6} \mathrm{~F}_{5}\right)_{4}\right]^{-}$-type complexes. In contrast, the corresponding species formed in the reaction of half-metallocene titanium complexes $\left[\left(\eta^{5}-\mathrm{Me}_{4} \mathrm{C}_{5}\right) \mathrm{Si}(\mathrm{Me})_{2}\left(\mathrm{k}-\mathrm{N}^{\mathrm{t} B u}\right)\right] \mathrm{Ti}(\mathrm{Me})_{2}\left(5-\mathrm{TiMe}_{2}\right),\left[\left(\eta^{5}-\mathrm{Me}_{4} \mathrm{C}_{5}\right)\left(\mathrm{C}_{9} \mathrm{H}_{9}(\mathrm{k}-\mathrm{N})\right)\right] \mathrm{Ti}(\mathrm{Me})_{2}$ $\left(6-\mathrm{TiMe}_{2}\right)$, and $\left[\left(\eta^{5}-\mathrm{Me}_{3} \mathrm{C}_{7} \mathrm{H}_{1} \mathrm{~S}\right)\left(\mathrm{C}_{10} \mathrm{H}_{11}(\mathrm{k}-\mathrm{N})\right)\right] \mathrm{Ti}(\mathrm{Me})_{2}\left(7-\mathrm{TiMe}_{2}\right)$ with $\left[\mathrm{Me}\left(\mathrm{C}_{18} \mathrm{H}_{37}\right)_{2} \mathrm{~N}-\mathrm{H}\right]^{+}$ $\left[\mathrm{B}\left(\mathrm{C}_{6} \mathrm{~F}_{5}\right)_{4}\right]^{-}$were unstable for subsequent transformation to other species (presumably, [L-Ti $\left.\left(\mathrm{CH}_{2} \mathrm{~N}\left(\mathrm{C}_{18} \mathrm{H}_{37}\right)_{2}\right)\right]^{+}\left[\mathrm{B}\left(\mathrm{C}_{6} \mathrm{~F}_{5}\right)_{4}\right]^{-}$-type complexes). The addition of excess (1.5 equiv.) $\left[\mathrm{Me}\left(\mathrm{C}_{18} \mathrm{H}_{37}\right)_{2} \mathrm{~N}-\mathrm{H}\right]^{+}\left[\mathrm{B}\left(\mathrm{C}_{6} \mathrm{~F}_{5}\right)_{4}\right]^{-}$suppressed the formation of side products, especially in the cases of $4-\mathrm{HfMe}_{2}, 5-\mathrm{TiMe}_{2}, 6-\mathrm{TiMe}_{2}$, and 7-TiMe $\mathrm{T}_{2}$. With the aim of preventing further transformation, 5- $\mathrm{TiCl}(\mathrm{Me})$ and 6- $\mathrm{TiCl}(\mathrm{Me})$ were prepared, from which $[\mathrm{L}-\mathrm{TiCl}(\mathrm{N}(\mathrm{H})$ $\left.\left.\left(\mathrm{C}_{18} \mathrm{H}_{37}\right)_{2}\right)\right]^{+}\left[\mathrm{B}\left(\mathrm{C}_{6} \mathrm{~F}_{5}\right)_{4}\right]^{-}$-type complexes were successfully prepared. The [L-M(Me)(NMe $\left.\left.\left(\mathrm{C}_{18} \mathrm{H}_{37}\right)_{2}\right)\right]^{+}\left[\mathrm{B}\left(\mathrm{C}_{6} \mathrm{~F}_{5}\right)_{4}\right]^{-}$, $\left[\mathrm{L}-\mathrm{Ti}\left(\mathrm{CH}_{2} \mathrm{~N}\left(\mathrm{C}_{18} \mathrm{H}_{37}\right)_{2}\right)\right]^{+}\left[\mathrm{B}\left(\mathrm{C}_{6} \mathrm{~F}_{5}\right)_{4}\right]^{-}$, and $\left[\mathrm{L}-\mathrm{TiCl}\left(\mathrm{N}(\mathrm{H})\left(\mathrm{C}_{18} \mathrm{H}_{37}\right)_{2}\right)\right]^{+}$ $\left[\mathrm{B}\left(\mathrm{C}_{6} \mathrm{~F}_{5}\right)_{4}\right]^{-}$-type species, which are soluble and stable in aliphatic hydrocarbon solvents (e.g., methylcyclohexane and $\mathrm{C}_{6} \mathrm{D}_{12}$ ), were highly active in ethylene/1-octene copolymerization performed in aliphatic hydrocarbon solvents (e.g., hexane). Feeding the activated species to a polymerization reactor (instead of in situ generation of the activated species in a bulk reactor) might be advantageous in running a commercial process.

\section{Patents}

Patents were applied on this study (Ajou University, high-purity ammonium borate and a method for preparing the same, Kr 10-2020-0104473, 20 August 2020; Ajou University, halogenation of group 4 dimethyl olefin polymerization catalysts, Kr 10-2021-0045949, 08 April 2021).

Supplementary Materials: The following are available online. Figure S1: $\mathrm{Ag}^{+}$ion test results for $\left[(\mathrm{Me})\left(\mathrm{C}_{18} \mathrm{H}_{37}\right)_{2} \mathrm{~N}-\mathrm{H}\right]^{+}\left[\mathrm{B}_{(}\left(\mathrm{C}_{6} \mathrm{~F}_{5}\right)_{4}\right]^{-}$; Figure S2: ${ }^{1} \mathrm{H}$ NMR spectrum (recorded in $\mathrm{C}_{6} \mathrm{D}_{6}$ ) for the sample in which water was deliberately added to the high purity $\left[(\mathrm{Me})\left(\mathrm{C}_{18} \mathrm{H}_{37}\right)_{2} \mathrm{~N}-\mathrm{H}\right]^{+}\left[\mathrm{B}\left(\mathrm{C}_{6} \mathrm{~F}_{5}\right)_{4}\right]^{-}$prepared according to Scheme $2 \mathrm{~b}$; Figures $\mathrm{S} 3$ and $\mathrm{S} 4:{ }^{1} \mathrm{H},{ }^{13} \mathrm{C}$, and ${ }^{19} \mathrm{~F}$ NMR spectra of $\left[\left(\mathrm{C}_{12} \mathrm{H}_{25}\right)_{3} \mathrm{~N}-\mathrm{H}\right]^{+}\left[\mathrm{B}\left(\mathrm{C}_{6} \mathrm{~F}_{5}\right)_{4}\right]^{-}$ and $\left[\left(\mathrm{C}_{18} \mathrm{H}_{37}\right)_{2} \mathrm{NH}_{2}\right]^{+}\left[\mathrm{B}\left(\mathrm{C}_{6} \mathrm{~F}_{5}\right)_{4}\right]^{-}$recorded in $\mathrm{C}_{6} \mathrm{D}_{6}$; Figure $\mathrm{S} 5:{ }^{1} \mathrm{H}$ NMR spectra of 6-TiCl(Me) and its activated complex $\left[6-\mathrm{TiCl}\left(\mathrm{N}(\mathrm{H})\left(\mathrm{CF}_{18} \mathrm{H}_{37}\right)_{2}\right)\right]^{+}\left[\mathrm{B}\left(\mathrm{C}_{6} \mathrm{~F}_{5}\right)_{4}\right]^{-}$; Figure $\mathrm{S} 6:{ }^{1} \mathrm{H}$ and ${ }^{13} \mathrm{C} \mathrm{NMR}$ spectra of 6- $\mathrm{TiCl}_{2}$ generated by reacting 6-TiMe 2 with 1 eq $\mathrm{ZnCl}_{2}$; Figures $\mathrm{S}-\mathrm{S} 10:{ }^{1} \mathrm{H}^{-1}{ }^{1} \mathrm{HCOSY},{ }^{13} \mathrm{C}_{,}{ }^{1} \mathrm{H}-{ }^{13} \mathrm{C}$ HSQC, and ${ }^{19} \mathrm{~F}$ NMR spectrum of $\left[1-\mathrm{Zr}(\mathrm{Me})\left(\mathrm{N}(\mathrm{Me})\left(\mathrm{C}_{18} \mathrm{H}_{37}\right)_{2}\right)\right]^{+}\left[\mathrm{B}\left(\mathrm{C}_{6} \mathrm{~F}_{5}\right)_{4}\right]^{-}$; Figure S11: ${ }^{1} \mathrm{H}$ NMR spectra of $\mathrm{Me}\left(\mathrm{C}_{18} \mathrm{H}_{37}\right)_{2} \mathrm{~N}$ and $\left[(\mathrm{Me})\left(\mathrm{C}_{18} \mathrm{H}_{37}\right)_{2} \mathrm{~N}-\mathrm{H}\right]^{+}\left[\mathrm{B}\left(\mathrm{C}_{6} \mathrm{~F}_{5}\right)_{4}\right]^{-}$recorded in $\mathrm{C}_{6} \mathrm{D}_{12} ;$ Figure S12: ${ }^{1} \mathrm{H}$ NMR spectra of 4- $\mathrm{HfMe}_{2}$ and its activated complex $\left[4-\mathrm{Hf}(\mathrm{Me})\left(\mathrm{N}(\mathrm{Me})\left(\mathrm{C}_{18} \mathrm{H}_{37}\right)_{2}\right)\right]^{+}\left[\mathrm{B}\left(\mathrm{C}_{6} \mathrm{~F}_{5}\right)_{4}\right]^{-} ;$Figure S13: ${ }^{1} \mathrm{H}$ NMR spectra of 5-TiMe $e_{2}$ and its reaction product with $\left[(\mathrm{Me})\left(\mathrm{C}_{18} \mathrm{H}_{37}\right)_{2} \mathrm{~N}-\mathrm{H}\right]^{+}\left[\mathrm{B}\left(\mathrm{C}_{6} \mathrm{~F}_{5}\right)_{4}\right]^{-}$; Figure S14: ${ }^{1} \mathrm{H}$ NMR spectra for the reaction of 6-TiMe 2 with $\left[\left(\mathrm{C}_{18} \mathrm{H}_{37}\right)_{2} \mathrm{NH}_{2}\right]^{+}\left[\mathrm{B}\left(\mathrm{C}_{6} \mathrm{~F}_{5}\right)_{4}\right]^{-}$in 10 min and in $2 \mathrm{~h}$; Figure S15: ${ }^{1} \mathrm{H}$ NMR spectra of 7-TiMe 2 and its activated complex $\left[7-\mathrm{Ti}\left(\eta^{1}-\mathrm{CH}_{2}\right) \mathrm{N}\left(\mathrm{C}_{18} \mathrm{H}_{37}\right)_{2}\right]^{+}\left[\mathrm{B}\left(\mathrm{C}_{6} \mathrm{~F}_{5}\right)_{4}\right]^{-}$formed at an initial stage which was transformed to another species after overnight. 
Author Contributions: Investigation, H.-J.L., J.-W.B., Y.-H.S., H.-C.L., and S.-M.J.; formal analysis, J.L.; validation, C.-G.L.; conceptualization, funding acquisition, supervision, and writing, B.-Y.L. All authors have read and agreed to the published version of the manuscript.

Funding: C1 Gas Refinery Program (2019M3D3A1A01069100) and Priority Research Centers Program (2019R1A6A1A11051471).

Institutional Review Board Statement: Not applicable.

Informed Consent Statement: Not applicable.

Data Availability Statement: The data that support the findings of this study are available from the corresponding author upon reasonable request.

Conflicts of Interest: Ajou University (inventors: H. J. Lee, J. W. Baek, and B. Y. Lee) have applied patents covering the preparation methods of high-purity ammonium salts and L-MCl(Me) L-MCl2 type complexes.

Sample Availability: Samples of $\left[(\mathrm{Me})\left(\mathrm{C}_{18} \mathrm{H}_{37}\right)_{2} \mathrm{~N}-\mathrm{H}\right]^{+}\left[\mathrm{B}\left(\mathrm{C}_{6} \mathrm{~F}_{5}\right)_{4}\right]^{-},\left[\left(\mathrm{C}_{12} \mathrm{H}_{25}\right)_{3} \mathrm{~N}-\mathrm{H}\right]^{+}\left[\mathrm{B}\left(\mathrm{C}_{6} \mathrm{~F}_{5}\right)_{4}\right]^{-}$, and $\left[\left(\mathrm{C}_{18} \mathrm{H}_{37}\right)_{2} \mathrm{NH}_{2}\right]^{+}\left[\mathrm{B}\left(\mathrm{C}_{6} \mathrm{~F}_{5}\right)_{4}\right]^{-}$are available from Precious Catalysts Inc.; cglee@s-pci.com (C.G.L.).

\section{References}

1. Kaminsky, W. Discovery of methylaluminoxane as cocatalyst for olefin polymerization. Macromolecules 2012, 45, 3289-3297. [CrossRef]

2. Nifant'ev, I.E.; Ivchenko, P.V.; Vinogradov, A.A. Heterocycle-fused cyclopentadienyl metal complexes: Heterocene synthesis, structure and catalytic applications. Coord. Chem. Rev. 2021, 426, 213515. [CrossRef]

3. Yuan, S.-F.; Yan, Y.; Solan, G.A.; Ma, Y.; Sun, W.-H. Recent advancements in N-ligated group 4 molecular catalysts for the (co)polymerization of ethylene. Coord. Chem. Rev. 2020, 411, 213254. [CrossRef]

4. Antonov, A.A.; Bryliakov, K.P. Post-metallocene catalysts for the synthesis of ultrahigh molecular weight polyethylene: Recent advances. Eur. Polym. J. 2021, 142, 110162. [CrossRef]

5. Phillips, A.M.F.; Suo, H.; Silva, M.D.F.C.G.D.; Pombeiro, A.J.L.; Sun, W.H. Recent developments in vanadium-catalyzed olefin coordination polymerization. Coord. Chem. Rev. 2020, 416, 213332. [CrossRef]

6. Liang, T.; Goudari, S.B.; Chen, C. A simple and versatile nickel platform for the generation of branched high molecular weight polyolefins. Nat. Commun. 2020, 11, 372. [CrossRef]

7. Tan, C.; Chen, C. Emerging palladium and nickel catalysts for copolymerization of olefins with polar monomers. Angew. Chem. Int. Ed. 2019, 58, 7192-7200. [CrossRef]

8. Velthoen, M.E.Z.; Boereboom, J.M.; Bulo, R.E.; Weckhuysen, B.M. Insights into the activation of silica-supported metallocene olefin polymerization catalysts by methylaluminoxane. Catal. Today 2019, 334, 223-230. [CrossRef]

9. Zaccaria, F.; Zuccaccia, C.; Cipullo, R.; Budzelaar, P.H.M.; Macchioni, A.; Busico, V.; Ehm, C. BHT-Modified MAO: Cage Size Estimation, Chemical Counting of Strongly Acidic Al Sites, and Activation of a Ti-Phosphinimide Precatalyst. ACS Catal. 2019, 9, 2996-3010. [CrossRef]

10. Resconi, L.; Bossi, S.; Abis, L. Study on the role of methylalumoxane in homogeneous olefin polymerization. Macromolecules 1990, 23, 4489-4491. [CrossRef]

11. Bae, S.M.; Jeong, S.M.; Baek, J.W.; Lee, H.J.; Kim, H.; Yoon, Y.; Chung, S.; Lee, B.Y. Dinuclear metallocene complexes for high-performance supported catalysts. Eur. Polym. J. 2021, 144, 110243. [CrossRef]

12. Dai, S.; Chen, C. A Self-supporting strategy for gas-phase and slurry-phase ethylene polymerization using late-transition-metal catalysts. Angew. Chem. Int. Ed. 2020, 59, 14884-14890. [CrossRef]

13. Chien, J.C.W.; Tsai, W.M.; Rausch, M.D. Isospecific polymerization of propylene catalyzed by rac-ethylenebis(indenyl)methyl zirconium cation. J. Am. Chem. Soc. 1991, 113, 8570-8571. [CrossRef]

14. Liu, D.; Wang, M.; Chai, Y.; Wan, X.; Cui, D. Self-activated coordination polymerization of alkoxystyrenes by a yttrium precursor: Stereocontrol and mechanism. ACS Catal. 2019, 9, 2618-2625. [CrossRef]

15. Nomura, K.; Pengoubol, S.; Apisuk, W. Synthesis of ultrahigh molecular weight polymers containing reactive functionality with low pdis by polymerizations of long-chain $\alpha$-olefins in the presence of their nonconjugated dienes by $\mathrm{Cp}^{*} \mathrm{TiMe}_{2}\left(\mathrm{O}-2,6-\mathrm{iPr} \mathrm{C}_{6} \mathrm{H}_{3}\right)-$ borate catalyst. Polymers 2020, 12, 3. [CrossRef]

16. Park, H.S.; Kim, T.H.; Baek, J.W.; Lee, H.J.; Kim, T.J.; Ryu, J.Y.; Lee, J.; Lee, B.Y. Extremely active ethylene tetramerization catalyst avoiding the use of methylaluminoxane: $\left[\mathrm{iPrN}\left\{\mathrm{P}\left(\mathrm{C}_{6} \mathrm{H}_{4}-p-\mathrm{SiR}_{3}\right)_{2}\right\}_{2} \mathrm{CrCl}_{2}\right]^{+}\left[\mathrm{B}\left(\mathrm{C}_{6} \mathrm{~F}_{5}\right)_{4}\right]^{-}$. ChemCatChem 2019, 11, 4351-4359. [CrossRef]

17. Kim, T.H.; Lee, H.M.; Park, H.S.; Kim, S.D.; Kwon, S.J.; Tahara, A.; Nagashima, H.; Lee, B.Y. MAO-free and extremely active catalytic system for ethylene tetramerization. Appl. Organometall. Chem. 2019, 33, e4829. [CrossRef]

18. Stennett, T.E.; Haddow, M.F.; Wass, D.F. Avoiding MAO: Alternative activation methods in selective ethylene oligomerization. Organometallics 2012, 31, 6960-6965. [CrossRef] 
19. Sian, L.; Macchioni, A.; Zuccaccia, C. Understanding the role of metallocenium ion-pair aggregates on the rate of olefin insertion into the metal-carbon bond. ACS Catal. 2020, 10, 1591-1606. [CrossRef]

20. Parveen, R.; Cundari, T.R.; Younker, J.M.; Rodriguez, G. Computational assessment of counterion effect of borate anions on ethylene polymerization by zirconocene and hafnocene catalysts. Organometallics 2020, 39, 2068-2079. [CrossRef]

21. Gao, Y.; Chen, J.; Wang, Y.; Pickens, D.B.; Motta, A.; Wang, Q.J.; Chung, Y.-W.; Lohr, T.L.; Marks, T.J. Highly branched polyethylene oligomers via group IV-catalysed polymerization in very nonpolar media. Nat. Catal. 2019, 2, 236-242. [CrossRef]

22. Nakashima, T.; Nakayama, Y.; Shiono, T.; Tanaka, R. Neutral, noncoordinating, and hydrocarbon-soluble protic cocatalyst for olefin polymerization. ACS Catal. 2021, 11, 865-870. [CrossRef]

23. Jia, L.; Yang, X.; Ishihara, A.; Marks, T.J. Protected (Fluoroaryl)borates as effective counteranions for cationic metallocene polymerization catalysts. Organometallics 1995, 14, 3135-3137. [CrossRef]

24. Faler, C.A.; Whalley, M.T.; Gadorn, J.R. A Process To Make Non-Coordinating Anion Type Activators in Aliphatic and Alicyclic Hydrocarbon Solvents. WO 2,019,210,029A1, 31 October 2019.

25. Zaccaria, F.; Zuccaccia, C.; Cipullo, R.; Budzelaar, P.H.M.; Vittoria, A.; Macchioni, A.; Busico, V.; Ehm, C. Methylaluminoxane's molecular cousin: A well-defined and "complete" al-activator for molecular olefin polymerization catalysts. ACS Catal. 2021, 11, 4464-4475. [CrossRef]

26. Romanato, P.; Duttwyler, S.; Linden, A.; Baldridge, K.K.; Siegel, J.S. Intramolecular halogen stabilization of silylium ions directs gearing dynamics. J. Am. Chem. Soc. 2010, 132, 7828-7829. [CrossRef]

27. Lee, S.; Park, S.S.; Kim, J.G.; Kim, C.S.; Lee, B.Y. Preparation of "constrained geometry" titanium complexes of [1,2]azasilinane framework for ethylene/1-octene copolymerization. Molecules 2017, 22, 258. [CrossRef]

28. Ali, A.; Muhammad, N.; Hussain, S.; Jamil, M.I.; Uddin, A.; Aziz, T.; Tufail, M.K.; Guo, Y.; Wei, T.; Rasool, G.; et al. Kinetic and thermal study of ethylene and propylene homo polymerization catalyzed by ansa-zirconocene activated with alkylaluminum/borate: Effects of alkylaluminum on polymerization kinetics and polymer structure. Polymers 2021, 13, 268. [CrossRef] [PubMed]

29. Nomura, K.; Pengoubol, S.; Apisuk, W. Synthesis of ultrahigh molecular weight polymers with low PDIs by polymerizations of 1-decene, 1-dodecene, and 1-tetradecene by $\mathrm{Cp}^{*} \mathrm{TiMe}_{2}\left(\mathrm{O}-2,6-\mathrm{iPr}_{2} \mathrm{C}_{6} \mathrm{H}_{3}\right)$-borate catalyst. Molecules 2019, 24, 1634. [CrossRef] [PubMed]

30. Cueny, E.S.; Johnson, H.C.; Anding, B.J.; Landis, C.R. Mechanistic Studies of hafnium-pyridyl amido-catalyzed 1-octene polymerization and chain transfer using quench-labeling methods. J. Am. Chem. Soc. 2017, 139, 11903-11912. [CrossRef] [PubMed]

31. Zuccaccia, C.; Macchioni, A.; Busico, V.; Cipullo, R.; Talarico, G.; Alfano, F.; Boone, H.W.; Frazier, K.A.; Hustad, P.D.; Stevens, J.C.; et al. Intra- and intermolecular NMR studies on the activation of arylcyclometallated hafnium pyridyl-amido olefin polymerization precatalysts. J. Am. Chem. Soc. 2008, 130, 10354-10368. [CrossRef] [PubMed]

32. Park, S.S.; Kim, C.S.; Kim, S.D.; Kwon, S.J.; Lee, H.M.; Kim, T.H.; Jeon, J.Y.; Lee, B.Y. Biaxial chain growth of polyolefin and polystyrene from 1,6-hexanediylzinc species for triblock copolymers. Macromolecules 2017, 50, 6606-6616. [CrossRef]

33. Ehm, C.; Mingione, A.; Vittoria, A.; Zaccaria, F.; Cipullo, R.; Busico, V. High-throughput experimentation in olefin polymerization catalysis: Facing the challenges of miniaturization. Ind. Eng. Chem. Res. 2020, 59, 13940-13947. [CrossRef]

34. Robert, K.R.; VanderLende, D.D. Highly Soluble Olefin Polymerization Catalyst Activator. U.S. Patent 5,919,983A, 6 July 1999.

35. Lee, J.C.; Park, K.L.; Bae, S.M.; Lee, H.J.; Baek, J.W.; Lee, J.; Sa, S.; Shin, E.J.; Lee, K.S.; Lee, B.Y. Styrene moiety-carrying diorganozinc compound preparation for polystyrene-poly(ethylene-co-1-hexene)-polystyrene triblock copolymer production. Macromolecules 2020, 53, 7274-7284. [CrossRef]

36. Lee, H.J.; Baek, J.W.; Kim, T.J.; Park, H.S.; Moon, S.H.; Park, K.L.; Bae, S.M.; Park, J.; Lee, B.Y. Synthesis of long-chain branched polyolefins by coordinative chain transfer polymerization. Macromolecules 2019, 52, 9311-9320. [CrossRef]

37. Baek, J.W.; Kwon, S.J.; Lee, H.J.; Kim, T.J.; Ryu, J.Y.; Lee, J.; Shin, E.J.; Lee, K.S.; Lee, B.Y. Preparation of half- and post-metallocene hafnium complexes with tetrahydroquinoline and tetrahydrophenanthroline frameworks for olefin polymerization. Polymers 2019, 11, 1093. [CrossRef]

38. Christman, W.E.; Morrow, T.J.; Arulsamy, N.; Hulley, E.B. Absolute estimates of Pd $\mathrm{Pd}^{\mathrm{II}} \eta^{2}$-Arene) C-H acidity. Organometallics 2018, 37, 2706-2715. [CrossRef]

39. Lee, J.Y.; Mathur, R.S. Process For Producing Tetrakis(Fluoroaryl)Borate Salts. WO 2,005,105,816A1, 10 November 2005.

40. Park, J.T.; Woo, B.W.; Yoon, S.C.; Shim, S.C. An efficient synthetic method of ansa-zirconocene dimethyl complexes via $\mathrm{Me}_{2} \mathrm{ZrCl}_{2}$. J. Organometall. Chem. 1997, 535, 29-32. [CrossRef]

41. Wu, C.J.; Lee, S.H.; Yun, H.; Lee, B.Y. Ortho Lithiation of tetrahydroquinoline derivatives and its use for the facile construction of polymerization catalysts. Organometallics 2007, 26, 6685-6687. [CrossRef]

42. Kim, S.H.; Park, J.H.; Song, B.G.; Yoon, S.W.; Go, M.J.; Lee, J.; Lee, B.Y. Preparation of thiophene-fused and tetrahydroquinolinelinked cyclopentadienyl titanium complexes for ethylene/ $\alpha$-olefin copolymerization. Catalysts 2013, 3, 104-124. [CrossRef]

43. Grandini, C.; Camurati, I.; Guidotti, S.; Mascellani, N.; Resconi, L.; Nifant'ev, I.E.; Kashulin, I.A.; Ivchenko, P.V.; Mercandelli, P.; Sironi, A. Heterocycle-fused indenyl silyl amido dimethyl titanium complexes as catalysts for high molecular weight syndiotactic amorphous polypropylene. Organometallics 2004, 23, 344-360. [CrossRef]

44. Resconi, L.; Camurati, I.; Grandini, C.; Rinaldi, M.; Mascellani, N.; Traverso, O. Indenyl-amido titanium and zirconium dimethyl complexes: Improved synthesis and use in propylene polymerization. J. Organometall. Chem. 2002, 664, 5-26. [CrossRef] 
45. Chen, Y.-X.; Marks, T.J. “Constrained geometry" dialkyl catalysts. Efficient syntheses, C-H bond activation chemistry, monomer-dimer equilibration, and $\alpha$-olefin polymerization catalysis. Organometallics 1997, 16, 3649-3657. [CrossRef]

46. Rocchigiani, L.; Zuccaccia, C.; Zuccaccia, D.; Macchioni, A. Self-aggregation tendency of zirconocenium ion pairs which model polymer-chain-carrying species in aromatic and aliphatic solvents with low polarity. Chem. Eur. J. 2008, 14, 6589-6592. [CrossRef] [PubMed]

47. Rocchigiani, L.; Bellachioma, G.; Ciancaleoni, G.; Macchioni, A.; Zuccaccia, D.; Zuccaccia, C. Synthesis, characterization, interionic structure, and self-aggregation tendency of zirconaaziridinium salts bearing long alkyl chains. Organometallics 2011, 30, 100-114. [CrossRef]

48. Rocchigiani, L.; Macchioni, A.; Zuccaccia, C. NMR Studies on the dynamic behavior of zirconaaziridinium ion pairs in solution. Organometallics 2012, 31, 4076-4079. [CrossRef]

49. Kumawat, J.; Gupta, V.K. Single to multiple site behavior of metallocenes through C-H activation for olefin polymerization: A mechanistic insight from DFT. ACS Catal. 2020, 10, 1704-1715. [CrossRef]

50. Kwon, S.J.; Baek, J.W.; Lee, H.J.; Kim, T.J.; Ryu, J.Y.; Lee, J.; Shin, E.J.; Lee, K.S.; Lee, B.Y. Preparation of pincer hafnium complexes for olefin polymerization. Molecules 2019, 24, 1676. [CrossRef] [PubMed]

51. Zuccaccia, C.; Tensi, L.; Kuhlman, R.L.; Gies, A.P.; Macchioni, A. C-H Activation and olefin insertion as sources of multiple sites in olefin polymerization catalyzed by $\mathrm{Cp}^{\mathrm{Alkyl}} \mathrm{Hf}(\mathrm{IV})$ complexes. ACS Catal. 2017, 7, 563-567. [CrossRef]

52. Laur, E.; Louyriac, E.; Dorcet, V.; Welle, A.; Vantomme, A.; Miserque, O.; Brusson, J.-M.; Maron, L.; Carpentier, J.-F.; Kirillov, E. Substitution effects in highly syndioselective styrene polymerization catalysts based on single-component allyl ansa-lanthanidocenes: An experimental and theoretical study. Macromolecules 2017, 50, 6539-6551. [CrossRef]

53. Cueny, E.S.; Johnson, H.C.; Landis, C.R. Selective quench-labeling of the hafnium-pyridyl amido-catalyzed polymerization of 1-octene in the presence of trialkyl-aluminum chain-transfer reagents. ACS Catal. 2018, 8, 11605-11614. [CrossRef]

54. Park, J.H.; Do, S.H.; Cyriac, A.; Yun, H.; Lee, B.Y. Preparation of half-metallocenes of thiophene-fused and tetrahydroquinolinelinked cyclopentadienyl ligands for ethylene/ $\alpha$-olefin copolymerization. Dalton Trans. 2010, 39, 9994-10002. [CrossRef] [PubMed] 